\title{
The Economic Effects of Technological Progress: Evidence from the Banking Industry
}

\author{
Allen N. Berger \\ Board of Governors of the Federal Reserve System \\ Washington, DC 20551 U.S.A. \\ and \\ Wharton Financial Institutions Center \\ Philadelphia, PA 19104 U.S.A.
}

Forthcoming, Journal of Money, Credit, and Banking, Volume 35, 2003

\begin{abstract}
$\underline{\text { Abstract }}$
This paper examines technological progress and its effects in the banking industry. Banks are intensive users of both IT and financial technologies, and have a wealth of data available that may be helpful for the general understanding of the effects of technological change. The research suggests improvements in costs and lending capacity due to improvements in "back-office" technologies, as well as consumer benefits from improved "front-office" technologies. The research also suggests significant overall productivity increases in terms of improved quality and variety of banking services. In addition, the research indicates that technological progress likely helped facilitate consolidation of the industry.
\end{abstract}

JEL Codes: O30, G21, G28, G34

Key Words: technological progress, productivity, banks, mergers, efficiency.

The opinions expressed do not necessarily reflect those of the Federal Reserve Board or its staff. The author thanks Ana Aizcorbe, Bob Avery, Paul Bauer, Mark Carey, Steve Cecchetti, Bill Dewald, Bob DeYoung, Paul Evans, Scott Frame, Fred Furlong, Geoff Gerdes, Michael Gordy, Diana Hancock, Dave Humphrey, Erik Kiefel, Leora Klapper, Beth Klee, Myron Kwast, Steve Oliner, Dan Nolle, Dan Sichel, Kevin Stiroh, Phil Strahan, Rick Sullivan, Greg Udell, Haluk Unal, Larry White, and seminar participants at the Journal of Money Credit and Banking Annual Lecture at Ohio State University for helpful suggestions, and Nate Miller for outstanding research assistance.

Please address correspondence to Allen N. Berger, Mail Stop 153, Federal Reserve Board, 20th and C Streets. NW, Washington, DC 20551, call 202-452-2903, fax 202-452-5295, or email aberger@frb.gov. 


\section{The Economic Effects of Technological Progress: \\ Evidence from the Banking Industry}

\section{Introduction}

This paper examines the available evidence on technological progress and its effects in the banking industry. Innovations in information processing, telecommunications, and related technologies - known collectively as "information technology" or "IT" - are often credited with helping fuel strong growth in the U.S. economy, although questions remain about the relative importance of IT versus other factors. The extensive research on the banking industry may help in the general understanding about the effects of technological change. The category of Depository and Nondepository Financial Institutions - of which banking is an integral part - is the most IT-intensive industry in the U.S. as measured by the ratio of computer equipment and software to value added (Triplett and Bosworth 2002, Table 2).

Banks are also significant users of financial technologies that employ economic and statistical models to create and value new securities, estimate return distributions, and make portfolio decisions based on financial data. Examples include financial engineering used to create new financial derivatives, credit risk and market risk models employed to improve portfolio management, and modern credit scoring and discriminant analysis used to evaluate credit applications. These financial technologies often depend heavily on the use of IT to collect, process, and disseminate the data, as well as on economic and statistical models to evaluate the data. Technological progress in the banking industry is also important because of the key roles of banks in providing financing, deposit, and payments services to other sectors of the economy.

We assess the effects of technological progress on productivity growth in the banking industry and on the structure of this industry. The use of a single industry with relatively homogenous inputs and outputs may help mitigate problems of combining data from heterogeneous industries. Research on banking benefits as well from detailed data on individual firms to specify cost and profit functions and control for differing business conditions when measuring productivity change, scale economies, and other performance indicators. Some special banking data sets also allow for observation of specific technological changes and measurement of some of their effects. In addition, detailed information on the scale, geographic spread, and merger and acquisition (M\&A) activity of individual banks aid in evaluating the effects of technological progress on the structure of the industry, i.e., the extent to which technological progress facilitates industry consolidation.

Study of the banking industry also demonstrates some of the general problems in measuring the effects of technological progress and how these problems might be addressed. For example, to the extent that markets 
are competitive, the benefits from technological advances in an industry may be competed away and passed through to customers or factors of production and not measured as productivity increases in that industry. As shown below, banks may have essentially "given away" the benefits from the ATM technology in the 1980s as the industry became more competitive due to deregulation and rents from market power shifted to consumers. It has been shown elsewhere how new products and quality improvements from technological progress are often neglected in government statistics and may lead to overstatements of inflation and understatements of productivity growth. In banking, there are many new products and quality improvements that are not easily captured in standard productivity measures, and we show how some may be measured in alternative ways.

The paper is organized as follows. Section 2 shows some background statistics on changes in the banking industry over time. Section 3 reviews microeconomic research on examples of technological changes in the banking industry that provide some potential general inferences about new technologies. Sections 4 and 5 discuss the research on the two main consequences of technological progress in banking examined in this paper, productivity growth and the structure of the industry, respectively. Section 6 concludes.

\section{Changes in the banking industry over time}

We present statistics that illustrate some of the changes in technology, performance, and structure of the banking industry. Table 1 gives data on changes in the structure of the commercial banking industry annually over the period 1984-2001, which illustrate the consolidation of the industry. The total number of banking organizations (top-tier holding companies plus independent banks) and the number of banks substantially declined over the 17-year period at average annual rates of 3.3\% and 3.4\%, respectively, even while gross total assets (GTA) grew by $3.0 \%$ per year. The consolidation has primarily occurred through mergers and acquisitions (M\&As) that combine institutions in different local markets - the average local market Herfindahl index has increased by only $1.1 \%$ annually.

Table 1 also provides data on changes in the use of selected banking technologies, indicating significant growth in the use of new IT and financial technologies. The number of physical banking offices using human tellers has expanded at a 2.1\% annual rate, whereas the number of IT-based ATMs has expanded at a $10.1 \%$ annual rate, so that ATMs now outnumber physical offices by more than four to one. ${ }^{1}$ As

\footnotetext{
${ }^{1}$ Physical offices include both traditional stand-alone brick-and-mortar offices plus some of the newer, smaller offices located in supermarkets and shopping centers.
} 
illustrations of the proliferation of financial technologies, the notional values of credit commitments (standby letters of credit, commercial and similar letters of credit, commitments, and participations in acceptances) and interest rate swaps (the only derivatives with available data back to the mid-1980s) have also grown at much faster rates than bank assets, $9.2 \%$ and $27.9 \%$, respectively, annually in real terms. ${ }^{2}$

Table 2 shows selected data on changes in the structure of financial markets. The data suggest that public financial markets have grown much faster than the 3.0\% annual rate of bank GTA. Money market mutual funds, an alternative to bank deposits, grew at an average annual rate of 10.8\% from 1984-2001. Corporate equity and corporate debt (bonds plus commercial paper), which are alternatives to bank loans, grew at annual rates of $10.0 \%$ and $11.3 \%$, respectively, overtaking bank GTA by 2001 . Finally, mortgage pools and other asset-backed securities - some of which are assets that were removed from bank balance sheets and some of which are alternatives to bank financing - grew at an annual rate of $13.7 \%$ over the interval.

These data are consistent with the hypothesis that advances in IT and financial technologies have helped these financial markets to grow at faster rates than the banking industry. Money market mutual funds were helped by IT innovations that let them store, keep track of, and move large amounts of information on securities and customer accounts much more cheaply over time. Public equity and debt markets were similarly favored by IT innovations for handling data, and were also propelled by reductions in trading costs. Much of the trading is now done electronically and the costs per trade have fallen dramatically. Asset-backed securities markets were aided by these IT innovations and by financial innovations that allow for more accurate pricing, more securitization instruments, and better risk management models.

Table 3 displays some statistics on the performance of the banking industry over time as measured by accounting ratios (market measures are not available for most banks). Return on equity and return on assets are measures of overall performance; total costs/GTA is a measure of total costs per dollar to create assets, which is also broken out by noninterest and interest expenses to GTA; revenues/total costs is sometimes used as an efficiency measure; and the nonperforming loan ratio, NPL/Loans, is an indicator of problem loans that have not yet been charged off. The banking industry had sustained good performance after 1991, although the cost

\footnotetext{
${ }^{2}$ Some bank growth is due to banking organizations buying thrifts and to the conversion of thrifts into commercial banks. Examination of the data inclusive of thrifts suggests qualitatively similar conclusions. The average annual growth in the total number of banks plus thrifts was - $4.0 \%$ compared to $-3.4 \%$ for banks alone, the combined total GTA annual growth rate was $2.4 \%$ compared to $3.0 \%$, and the combined growth rate for physical offices was $0.7 \%$ compared to $2.1 \%$.
} 
reductions are primarily due to declining interest expenses, rather than noninterest expenses. Record profits were earned during several years in the 1990s, although performance may be slightly worse after 1999 . The extent to which the good performance reflects productivity gains from technological progress versus favorable market interest rates and other business conditions is investigated in Section 4 below.

Table 4 shows most of the performance measures as well as the number of banks and share of industry assets by size class. Two findings are apparent. First, banks in the smallest size class (GTA under $\$ 100$ million) tended to have worse performance than other banks in recent years. Second, there is consolidation of the industry into the largest size class (GTA greater than $\$ 10$ billion). The number of banks in the largest size class increased from 38 to 69 and the proportion of industry assets in this class increased from $39.4 \%$ to $69.2 \%$ over the 17-year period. The number of banks in the smallest size class fell by more than half from almost 11,000 to less than 5,000, and the share of assets in this class fell by more than two-thirds from $12.7 \%$ to $4.0 \%$. The middle two size classes each lost some of their banks and almost half of their industry shares. Evidence presented below will suggest that technological progress played a role in this consolidation.

\section{Examples of technological changes in the banking industry}

Rather than reviewing microeconomic research on all banking technologies, we focus primarily on three examples in which the technological changes can be observed and some of their effects can be directly measured - Internet banking, electronic payments technologies, and information exchanges. ${ }^{3}$ These may not be the most important banking technologies, but they illustrate the multiplicity of potential different actual and measured effects of technological progress. Our examples also represent both IT and financial technologies and cover both "front-office" technologies in which the banks deal directly with customers and "back-office" technologies for producing services that are generally invisible to customers.

\section{A. Internet banking}

Internet banking is a relatively new front-office technology. Banks offer a variety of levels of Internet service and combinations of Internet and physical offices and ATM networks. Some banks employ a "clickand-mortar" implementation strategy in which the banks add a transactional Internet site to their physical

\footnotetext{
${ }^{3}$ See Frame and White (2002) for a general review of empirical research on the adoption and use of financial innovations, see Allen, McAndrews, and Strahan (2002) for discussion of research on the use of IT in the provision of financial services and markets or "e-finance," and see Claessens, Glaessner, and Klingebiel (2002) for an overview of the use of these different technologies around the world.
} 
offices and ATM networks. A transactional site allows customers to make transactions on-line such as accessing accounts, transferring funds, applying for a loan, etc. Other banks have set up informational websites that provide information about the banks and their services, but do not allow for on-line transactions. A small number of Internet-only banks offer services through transactional Internet sites and access to ATM networks, but with no physical offices open to the public. As of March 2002, there were 20 Internet-only banks and thrifts in the U.S. and approximately a dozen other such institutions have failed, been acquired, or voluntarily liquidated. ${ }^{4}$ A few large banks set up Internet-only units, and then integrated them into the main bank after poor performance. Finally, many banks continue to offer no Internet services.

Internet banking has become widespread in a short time, although there are substantial differences by bank size in implementation strategies. A study of national banks in the U.S. found that as of the end of 2000, $37.3 \%$ of these banks offered transactional Ipternet sites, and an additional $27.7 \%$ offered informational websites (Furst, Lang, and Nolle 2001, 2002). ${ }^{5}$ The vast majority of the transactional sites were set up since the beginning of 1998. The transactional website adoption rate varied greatly by bank size, with $100 \%$ of the banks with over $\$ 10$ billion in assets having these sites and only $20.0 \%$ of banks with less than $\$ 100$ million in assets. Since the large banks also have extensive physical branching and ATM networks, these banks are using the click-and-mortar implementation strategy. By the end of 2001, a number of banks had added transactional sites, but the rest of the relevant facts remained qualitatively unchanged $-49.7 \%$ of national banks had transactional websites (100\% of the largest banks, $29.1 \%$ of the smallest banks), and $21.7 \%$ had informational sites. $^{6}$ Although only about half of the national banks offer transactional Internet sites, those with transactional sites serve the vast majority of bank customers because they tend to include the largest banks $\square^{\text {A survey of }}$ banks in the Tenth Federal Reserve District (Kansas City District) yielded consistent findings. ${ }^{7}$

Importantly, although there may be scale economies in setting up and maintaining transactional

\footnotetext{
${ }^{4}$ The data on Internet-only institutions were provided by Federal Deposit Insurance Corporation staff.

${ }^{5}$ National banks are chartered by the Office of the Comptroller of the Currency, and include many of the largest banks.

${ }^{6}$ The data for the national banks for the end of 2001 were provided by Office of the Comptroller of the Currency staff.

${ }^{7}$ In the Tenth District in 2001, 28\% of responding banks had transactional Internet sites (100\% of the banks with assets over $\$ 1$ billion in assets and slightly less than $20 \%$ of banks with assets less than $\$ 150$ million), and $9 \%$ had informational sites (Sullivan 2001). It was also found that the probability of adopting a transactional website was increasing in bank size after controlling for other market and bank characteristics (Courchane, Nickerson, and Sullivan 2002). The smaller percentage of banks offering Internet services in these studies presumably reflects the high representation of small banks in the Tenth District relative to national banks.
} 
websites, this technology may still be accessed by small banks. Many small banks are able to outsource the provision of their transactional websites to companies that specialize in these operations.

Some studies have examined the relative performance of banks offering Internet services. For national banks with assets over $\$ 100$ million, those offering transactional Internet sites were more profitable than those that did not. This primarily reflects the choice of profitable banks to adopt the technology, rather than profitability from Internet services, which currently make up a small portion of output of most of these banks (Furst, Lang, and Nolle 2001, 2002). This research also found that for small banks with assets below $\$ 100$ million, there was no statistical difference in profitability between Internet and non-Internet banks for mature institutions in operation more than three years. However, for small de novo institutions with less than three years experience, those with transactional sites performed relatively poorly. A study of the relatively few Internet-only banks found that these banks performed more poorly than traditional de novo banks, consistent with the finding above that some Internet-only banks and units were discontinued due to poor performance. However, the performance of the Internet-only banks may be improving faster than other banks as they ride the learning curve and/or become able to exploit what may be substantial scale economies (DeYoung 2002).

The fast spread of Internet banking may result in the benefits of this technology going primarily to consumers as banks incur the costs of providing these sites to maintain market shares. That is, competition may currently or in the near future force banks to adopt the technology just to keep existing customers and not charge enough to earn abnormal profits from providing this service. Consistent with this possibility, banks offering Internet sites and those planning to adopt them generally referred to a need to remain competitive and retain customers, rather than any increase in revenues to cover their costs (Furst, Lang, and Nolle 2001, 2002, Sullivan 2001). This is similar to the experience of U.S. banks adding ATM networks in the early 1980s without charging the full costs of implementing that technology due to increased competitive pressures. ${ }^{8}$

\section{B. Electronic payments technologies}

Elegtronic payments technologies are methods of transferring funds electronically with relatively little paperwork. ${ }^{9}$ At the front-office level, there has been a switch from paper payments to electronic payments by

\footnotetext{
${ }^{8}$ One study using European data also found that Internet penetration reduced the sunk costs of market entry, increasing banking market contestability and yielding more favorable prices for customers (Corvoisier and Gropp 2001).

${ }^{9}$ For more extensive reviews of payments research, see Berger, Hancock, and Marquardt (1996) and Hancock and Humphrey (1998).
} 
the U.S. population. As shown next, consumers have switched some of their purchases from checks and cash to credit cards, which are mostly cleared electronically (except for the monthly paper bill and check payment), and to debit cards, which are almost entirely processed electronically.

One study found that the estimated number of checks paid in the U.S. fell by a statistically significant 7.0 billion from 49.5 billion in 1995 to 42.5 billion in 2000, an average annual rate of decline of $3.0 \%$. During the same interval, estimated credit card payments grew from 10.4 billion to 15.0 billion, an average annual increase of $7.3 \%$, and debit card transactions grew from an estimated 1.4 billion to 8.3 billion, an average annual growth rate of $35.6 \%$ (Gerdes and Walton 2002, Table 2). Thus, by these estimates, the share of checks to total checks plus credit and debit cards used fell from $80.8 \%$ to $64.6 \%$ in just five years.

Another study found that check use continued to grow, but at a much reduced pace, and that the use of cash in retail payments has declined dramatically. As a result, both types of paper payments have lost market shares to electronic payments. This study estimated that from 1990 to 2000, the share of cash used in personal consumption spending fell from $25.7 \%$ to $16.3 \%$, while the check share dropped from $61.8 \%$ to $56.0 \%$. During the same interval, the estimated credit card share rose from $12.2 \%$ to $21.2 \%$, and the estimated debit card share grew from $0.4 \%$ to $6.5 \%$ (Humphrey 2002). Thus, according to these estimates, the share of cash and checks used in personal consumption fell from $87.5 \%$ to $72.3 \%$ in a ten-year interval.

Another indicator of the switch from paper to electronics is the steep increase in the use of automated clearinghouse $(\mathrm{ACH})$, which is primarily a substitute for paper checks for regular payments, such as direct deposit of pay, withdrawal of monthly mortgage payments, etc. From 1990 to 2000, ACH volume processed by the Federal Reserve (which handles the majority of ACH payments) more than quadrupled from about 915 million in 1990 to 3.8 billion in 2000, a $\square^{2 \%}$ annual rate of increase (Annual Reports of the Board of Governors of the Federal Reserve System). ${ }^{10}$

It is likely that the switch from paper to electronic payments was fueled in large part by IT advances that reduced the costs and increased the availability and convenience of electronic payments. Consumer payments by credit card and debit card have become available at many more physical retail outlets (e.g.,

\footnotetext{
${ }^{10}$ Private-sector ACH payments may currently be increasing at an even faster pace. For example, Electronic Payments Network (EPN) processed 167 million transactions in May 2000, up 110\% from June 2001 (Electronic Payments Network Press Release, June 20, 2002, http://www.epaynetwork.com/wells.htm).
} 
grocery stores) and for more Internet and phone purchases. ${ }^{11}$

Cost studies of electronic payments processing are consistent with the notion that IT improvements in back-office processing of electronic payments resulted in productivity gains and scale economies that reduced costs dramatically over time. The studies often focus on the Federal Reserve because it is the largest processor and its data are available. However, the results likely generalize to the private sector because all processors have access to the same technologies and because the Federal Reserve is required to simulate the behavior of a private-sector competitor by keeping costs under control and set prices to recover costs.

The two main types of electronic payments processed by the Federal Reserve have had steep declines in unit costs over time. The raw data on $\mathrm{ACH}$ showed a decline in nominal unit costs from $\$ 0.869$ per item processed to $\$ 0.176$ over the $1990-2000$ interval. Put into real 1994 dollars using the GDP deflator yields a decline from $\$ 0.959$ to $\$ 0.158$, or fall of about $83 \%$ in real unit costs. The raw data on Fedwire (used primarily for large-value wholesale payments) showed a decline in nominal unit costs from $\$ 1.029$ to $\$ 9.518$ or from $\$ 1.135$ to $\$ 0.466$ in real unit costs over $1990-2000$, or a decline of about $59 \%$ in real terms. ${ }^{12}$ Given these remarkable declines in Federal Reserve unit costs, it seems reasonable to presume that substantial unit cost savings have also occurred for private sector electronic payments processing.

Cost function studies of $\mathrm{ACH}$ operations - which control for the input prices, output quantities, and other conditions - found very substantial improvements in cost productivity over time, although the improvements were smaller in last few years of the 1990s (Bauer and Hancock 1995, Bauer and Ferrier 1996, Bauer and Higgins 2002). Some of these improvements are clearly due to IT advances. For example, prior to the 1990s, ACH was run primarily as batch jobs with the physical delivery of computer tapes from the banks, whereas the data are now sent electronically. Part of the gains were also found to be due to the exploitation of scale economies, and the studies suggest that even more scale economies may remain unexploited. The Federal Reserve shifted in 1996 to FedACH, a centralized ACH application software to process payments, and consolidated the customer support sites from the 12 Districts to 2 sites in 2001.

\footnotetext{
${ }^{11}$ To some extent, the shift from paper to electronic payments may also be affected by issues of market power and legal rights. For example, there is now a legal action pending between several large retailers and large card issuers. The issue concerns the Visa's and MasterCard's "honor all cards" rule in which retailers must accept Visa and MasterCard (signature) debit cards in order to accept their credit cards.

${ }^{12}$ Based on Federal Reserve PACS data set for costs, Annual Reports for volume for both ACH and Fedwire.
} 
Studies of Fedwire processing also found substantial technological progress and scale economies linked to IT that allowed the Federal Reserve to consolidate from 36 processing sites to 3 sites (one main, two back-up, see Bauer and Ferrier 1996, Hancock, Humphrey, and Wilcox 1999). A difficult issue in switching to new technologies is adjustment costs (having extra machines and personnel during the transition, training costs, severance pay, etc.) One of the Fedwire studies was able to capture some of these adjustment costs and found them to be substantial, suggesting that the productivity gains may be even higher in the long run after the adjustment costs have subsided (Hancock, Humphrey, and Wilcox 1999). Adjustment costs will return as an issue in productivity studies and in bank M\&A studies. ${ }^{13}$

Importantly, although there may be substantial scale economies to processing payments, it is not necessary to have large banks to exploit these economies. Small banks can share some of these benefits by outsourcing to a large processor, such as the Federal Reserve, correspondent bank, or other large private-sector processor. Nonetheless, there may be differences by bank size in the use of these technologies, even when most of the processing is performed by a third party. ${ }^{14}$

\section{Information exchanges}

Information exchanges, as we use the term here, are intermediaries through which banks and other creditors share data relevant to the creditworthiness of loan applicants. These exchanges collect data from financial institutions, trade creditors, public records, and other sources, aggregate and summarize the data, and then provide credit reports or credit scores to lending institutions. The exchanges may be private thirq-farty credit bureaus, associations organized by banks, or public credit registers organized by central banks. ${ }^{15}$

The technology of information exchanges has been shown to add value. A cross-country analysis found that bank lending is higher and default rates are lower in nations in which lenders use either private or public information exchanges (Jappelli and Pagano 1999). In the U.S., a study found that information generated by Dun and Bradstreet (based in large part on trade credit information) added significant explanatory

\footnotetext{
${ }^{13}$ The research also suggests that technological progress has reduced the costs of processing paper check and cash payments, although these cost reductions have generally been much smaller than those for processing electronic payments (e.g., Bauer and Ferrier 1996, Bohn, Hancock, and Bauer 2001, Gilbert, Wheelock, and Wilson 2002).

${ }_{14}$ For example, a study based of ACH usage found that larger banks were more likely to make originations, although the gap between large and small banks was narrowing over time as usage increased (Gowrisankaran and Stavins 2002).

${ }^{15}$ In some cases, the exchanges collect only negative information, such as defaults or arrears, and in other cases also include positive information, such as loan repayments, employment history, etc. See Jappelli and Pagano (1999) for a detailed survey of theory and practice of information exchanges.
} 
power in predicting firm failure, even after controlling for other information available to lenders (Kallberg and Udell 2002a). Research on consumer credit scoring in the U.S. also generally found that the scores are the best predictors of repayment, with only minor improvements from additional data such as household income and location (e.g., Avery, Bostic, Calem, and Canner 2000). The use of information exchanges has also been shown to enhance the availability of credit in less developed nations (e.g., Klapper and Kraus 2002).

The information exchange technology is also subject to substantial scale economies. For example, additional observations of payments and other information tend to increase the quality of the credit signals (Pagano and Jappelli 1993, Kallberg and Udell 2002b). Technological progress has likely increased the productivity and scale economies associated with this technology as the data are now more often transmitted to and disseminated from information exchanges electronically, and improved financial models are used to analyze the data to predict future credit problems.

One technology that usually involves information exchanges is small business credit scoring (SBCS). Credit scores have long been used in underwriting consumer credits, but this technology has only recently been adapted to small commercial credits. The score is a summary statistic about the firm's expected future loan performance. A key element of this technology is the use of personal data about the owner of the business. Personal and business information are often obtained from credit bureaus and combined with data collected by the bank and entered into a loan-repayment prediction model (Mester 1997). It is a back-office technology, as customers typically do not know how their loan application is evaluated.

Fair, Isaac and Company, the largest provider of credit scoring models, introduced its first SBCS model in 1995, and many banks adopted SBCS in the succeeding years. The models are typically designedfor credits up to $\$ 250,000$, although many banks use the scores to evaluate credits of up to $\$ 100,000$ only. ${ }^{16}$

Several research studies employed a 1998 survey of large U.S. banking organizations on whether and how they used SBCS. These studies found that the use of scoring on small business credits under $\$ 100,000$ increased lending (Frame, Srinivasan, and Woosley 2001), that the lending was focused more on low- and moderate-income census tracts than on higher-income areas (Frame, Padhi, and Woosley 2001), and that the loans issued on average had higher interest rates and worse credit ratings than loans issued by non-scoring

\footnotetext{
${ }^{16}$ SBCS may eventually help to develop a secondary market for small business debt, similar to how consumer credit scoring helped develop secondary markets for consumer debt.
} 
institutions (Berger, Frame, and Miller 2002). These findings suggest a net increase in lending to "marginal applicants" that would not otherwise receive credit and tend to have relatively high loan prices and high risk when they are funded. The research also found that SBCS was generally adopted earlier by larger banks (Akhavein, Frame, and White 2001, Frame, Srinivasan, and Woosley 2001). However, banks of any size can access this technology by purchasing scores from third-party information exchanges.

The research also suggests that the way in which the technology is implemented is important. One study distinguished between banks that follow "rules" - use automated pricing and acceptance/denial decisions based on purchased credit scores - and banks that exercise "discretion" - develop their own scoring models and use other inputs in credit decisions (Berger, Frame, and Miller 2002). The expansion of credit was concentrated in the "rules" banks, with "discretion" banks primarily improving accuracy in credit evaluation. ${ }^{17}$

\section{Some potential inferences from the microeconomic research on banking technologies}

This research points to some potential general inferences about new technologies. First, there is a multiplicity of different actual and measured effects of new technologies on productivity growth and industry structure. Some new technologies - such as ATMs in the early 1980s and possibly Internet banking currently or in the near future - may increase productivity significantly in terms of the quality of the service to the consumer, but these benefits may not be easily measured. Firms may provide the higher quality without charging the full costs due to competitive pressures. In contrast, some new technologies - such as the innovations in processing electronic payments - may have very significant and easily observable effects in terms of productivity gains and increased scale economies. Some new technologies - such as innovations in information exchanges - may alternatively have significant benefits that can only be measured with nontraditional methods, such as examining the composition of the loan portfolio.

Second, the research on banking technologies suggests that most of the important new technologies were generally adopted earlier by large firms than small firms. Large banks have generally been first to 1) adopt transactional Internet websites, 2) use electronic payments technologies, and 3) employ the SBCS technology, although there are exceptions, such as some of the new Internet-only banks. The finding that large banks tend to adopt innovations earlier also holds for other banking technologies not reviewed in detail here

\footnotetext{
${ }^{17}$ The consequences were also found to change as individual banks and the banking industry as a whole gain experience with the new technology, and to be somewhat different for credits of $\$ 100,000$ to $\$ 250,000$.
} 
including the adoption of ATMs (e.g., Hannan and McDowell 1984), securitization and off-balance sheet financial activities (e.g., Berger and Udell 1993), and the new portfolio risk models for dealing with proposed Basle international capital standards. ${ }^{18}$

Third, the research suggests that even when there are significant scale economies associated with backoffice operations, small firms are often able to share in the benefits of technological progress. Small banks can 1) have transactional Internet sites by outsourcing to companies that specialize in these operations, 2) use electronic payments technologies by outsourcing to the Federal Reserve, correspondent bank, or other large private-sector processors, and 3) use information exchanges by purchasing data from a large exchange. Similarly, small banks can gain access to other large-scale technologies. For example, small banks in the U.S. take advantage of scale-efficient processing of paper payments provided by large institutions and are able to tap into nationwide and worldwide ATM networks without each bank setting up its own expansive network. Even some of the benefits of new complex risk management technologies may filter to banks too small to create their own systems through outsourcing, e.g., by purchasing portfolio risk models such as CreditMetrics or CreditRisk $^{+}$(Gordy 2000). However, access to these technologies does not necessarily mean that small banks can use these technologies at the same unit cost as large banks - the parties providing the back-office services may charge a relatively high fixed cost or offer significant volume discounts that put small banks at a disadvantage, which may help explain why small banks may be slower to adopt new technologies.

Fourth, the research suggests that the effects of a new technology may differ vary significantly with the way in which it is implemented. The research on front-office technologies suggests that combining new technologies with existing technologies to offer more consumer choice may often be the most effective implementation strategy. In the 1980s, banks generally combined the new ATM networks with traditional physical offices and today, the large banks that serve most customers are adding transactional Internet sites to their physical offices and ATM networks. For back-office technologies, the implementation strategy also appears to matter. The Federal Reserve appeared to achieve dramatically lower unit costs in processing

\footnotetext{
${ }^{18}$ There is also a substantial literature on other determinants of the use and adoption of banking technologies. These other determinants include market concentration and competition (e.g., Hannan and McDowell 1984, Akhavein, Frame, and White 2001, Courchane, Nickerson, and Sullivan 2002, Gowrisankaran and Stavins 2002, Hauswald and Marquez, forthcoming), the adoption by other banks or network externalities (e.g., Saloner and Shepard 1995, Molyneux and Shamroukh 1996, Gowrisankaran and Stavins 2002), the risk of the bank (e.g., Benveniste and Berger 1987, Avery and Berger 1991), and regulatory factors (e.g., Koppenhaver 1989, Jagtiani, Saunders, and Udell 1995).
} 
electronic payments in part by consolidating operations to take advantage of scale economies. The effects of small business credit scoring on lending also appear to vary considerably with whether the bank follows "rules" versus exercises more "discretion" and other factors.

\section{Technological progress and productivity growth}

We next examine the evidence linking technological progress to productivity growth. We include evidence on the aggregate economy as well as on the banking industry to provide background information and contrast the research methods and results.

\section{A. Technological progress and government indexes of aggregate and banking productivity growth}

Much has been made of the recent increased productivity growth for the U.S. economy as measured in government productivity indexes. Table 5, column 1, shows the Bureau of Labor Statistics (BLS) labor productivity measure for the U.S. private nonfarm business sector for 1967 through $2000(1996$ value $=100)$. Column 2 shows the one-year (continuous) growth rates or natural log differences between years t and t- 1 . An aggregate productivity slowdown is often identified as having occurred from about 1973-1995, and the recent upswing in productivity growth is often identified as having occurred approximately over 1995-2000. As shown, the average annual growth rate was $2.57 \%$ over $1967-1973$, which fell to $1.37 \%$ over $1973-1995$, and then rose to $2.54 \%$ over $1995-2000$, although there is significant variation within all of these intervals.

It is often argued that IT advances played a substantial role in the recent speedup, but the extent of this contribution is difficult to determine in part because many other events occurred over the same time period. Some have examined differences across industries and found that the highest productivity gains have generally occurred in industries that tend to use $\mathrm{IT}_{\mathrm{T}}$ intensively and those that manufacture IT equipment (e.g., McKinsey Global Institute 2001, Stiroh 2001). ${ }^{19}$

Some analysis has used modified forms of the Solow (1957) neoclassical growth model (e.g., Jorgenson and Stiroh 2000, Oliner and Sichel 2000). Essentially, aggregate output (Y) is modeled as a simple function of IT capital services $\left(\mathrm{K}_{\mathrm{IT}}\right)$, other capital services $\left(\mathrm{K}_{\mathrm{OTH}}\right)$, labor $(\mathrm{L})$, and a multifactor productivity term (MFP). Technological change is embodied in the MFP variable. A number of neoclassical assumptions are imposed, including perfect competition, constant returns to scale, no adjustment costs, equal returns to all types

\footnotetext{
${ }^{19}$ Regarding the manufacture of IT equipment, it is often pointed out how much more productive the semiconductor industry has become, roughly doubling the density of transistors on a chip every 18 months (Moore's Law).
} 
of capital, Hicks-neutral technological change, etc. The growth in labor productivity is given by:

$$
\Delta(\mathrm{Y} / \mathrm{L})=\alpha_{1} \Delta\left(\mathrm{K}_{\mathrm{IT}} / \mathrm{L}\right)+\alpha_{2} \Delta\left(\mathrm{K}_{\mathrm{OTH}} / \mathrm{L}\right)+\Delta \mathrm{MFP},
$$

where $\Delta$ denotes a growth rate, and the $\alpha$ are income shares. Technological progress is measured by the Solow residual or $\triangle \mathrm{MFP}$.

These studies generally found that IT contributed significantly to the recent upswing in aggregate productivity in two ways. First, the very large investments in IT equipment over time resulted in "capital deepening" or increases in $\Delta\left(\mathrm{K}_{\mathrm{IT}} / \mathrm{L}\right)$, growth in IT capital per unit of labor. Second, IT contributed to $\Delta \mathrm{MFP}$ primarily as a result of productivity gains in the production of this equipment.

Table 5, columns 3 and 4, show U.S. BLS labor productivity index for the commercial banking industry (SIC code 602, 1987 value $=100)$ and its one-year growth rates, respectively. For the 1967-1973, 1973-1995, and 1995-2000 intervals, the average annual growth rates were $2.26 \%, 2.01 \%$, and $2.50 \%$, respectively. Comparing these figures to those of the entire U.S. nonfarm business sector shown above $(2.57 \%, 1.37 \%$, and $2.54 \%$, respectively), suggests similar productivity growth rates for first and third intervals, but much less of a drop in productivity growth over 1973-1995.

A more important difference between the series (noted by Furlong 2001) lies in the timing of the start of the increase in measured productivity. Breaking up the banking series into the intervals 1967-1973, 19731982, and 1982-2000, gives average annual growth rates of $2.26 \%,-0.15 \%$, and $3.23 \%$, respectively. Thus, the BLS statistics suggest that the banking industry suffered a more significant drop in productivity than the nonfarm business sector starting after 1973, and had an even stronger recovery that occurred much earlier - in the early 1980s, rather than in the mid-1990s. As well, the strongest part of the growth was earlier than the 1995-2000 interval. It was suggested that this earlier measured upturn for the banking industrymay have occurred because banks generally invested heavily in IT before other industries (Furlong 2001). ${ }^{20}$

\footnotetext{
${ }^{20}$ The McKinsey Global Institute (2001) developed its own index for banking labor productivity. It uses the retail banking sector, which has a large overlap with commercial banking, but removes corporate lending and adds savings institutions. It found that annual productivity growth rates increased dramatically from-1.14\% over $1977-1982$ to $6.08 \%$ over 1982-1987, and then declined somewhat thereafter to $5.54 \%$ over $1987-1995$ to $4.13 \%$ over $1995-1999$. By way of contrast, the figures for these same time intervals using the BLS statistics are $-1.12 \%$ over $1977-1982,4.44 \%$ over 1982 1987, 2.93\% over 1987-1995, and 1.81\% over 1995-1999. While the McKinsey numbers are larger and more volatile, both series show the negative productivity growth over 1977-1982, a strong increase in the early 1980s, followed by declines in growth in the subsequent intervals.
} 


\section{B. Difficulties in linking technological progress to productivity growth}

There are a number of difficulties in linking technological progress to productivity growth. First, technological progress is usually difficult to quantify, and so must be inferred from changes in productivity ratios or firm performance over time. Since firms do not necessarily always employ the best available technology, observed changes in productivity or firm performance also reflect factors other than technological progress. Econometric analysis can at most estimate the best-practice frontier, which reflects the behavior of the best existing firms, but not the "true" efficient frontier that embodies the best available technology.

Second, it is difficult to account for the effects of technological progress in improving the quality and variety of goods and services. For example, prior research suggested that the introduction of high-technology consumer products such as cell phones, voicemail, and the Internet involved large increases in consumer welfare that went unmeasured in the U.S. Consumer Price Index (CPI) for many years (e.g., Hausman 1998). Research also suggested that improvements in quality associated with technological progress may have resulted in price indices that significantly overstate inflation (e.g., Pakes 2002). The Boskin Commission estimated that the CPI bias from new products and quality change was on the order of a $1.1 \%$ annual upward bias, with a plausible range of $0.8 \%$ to $1.6 \%$ (Boskin et al. 1996).

Third, the benefits from technological progress do not necessarily accrue to the firm or industry where they occur, making them difficult to measure. To the extent that markets are competitive, the associated rents may be competed away and passed through to customers or factors of production, provided there are no barriers to the adoption of the technology or in the product or factor markets. For example, if banking were perfectly competitive, and all technological improvements were successfully copied by other banks or nonbank competitors, any abnormal returns would be competed away through more favorable prices to customers (e.g., lower rates on loans, higher rates on deposits), improved quality and variety of services provided (e.g., ATMs, Internet banking), rents to the providers of the improved hardware/software (e.g., Intel, Microsoft), key employees that know how to use the technology, etc.

Fourth, the simplifying assumptions of the productivity models may be significantly violated by the data. For example, the $\triangle$ MFP residual in equation (1) above may embody factors other than the effects of technological progress if there is market power, increasing returns to capital, adjustment costs, unequal returns to different types of capital, non-neutral technological change, etc. One study found that adjustment costs to 
new technology during the late 1990s were substantial, suggesting that the contribution of technological progress to productivity growth may be higher than is usually measured and may be revealed more at a later date (Basu, Fernald, and Shapiro 2001). ${ }^{21}$

Some difficulties relate specifically to the government measures of bank productivity. The BLS statistics for commercial banking shown in Table 5 above, SIC code 602 , measures physical banking output using a "number-of-transactions" approach based on demand deposits (number of checks written and cleared, and number of electronic funds transfers), time deposits (weighted index of number of deposits and withdrawals on regular savings accounts, club accounts, CDs, money market accounts, and IRAs), ATM transactions, loans (indexes of new and existing real estate, consumer installment, and commercial loans, and number of bank credit card transactions), and number of trust accounts, weighted by the proportions of employee hours used in each activity. Employee labor hours are used as the denominator of the index. ${ }^{22}$

This measure does not include the financial market activities of banks (either on or off the balance sheet), and does not incorporate improvements in financial technologies except to the extent that they affect the amount of labor in doing traditional banking activities. By focusing on labor-weighted outputs, this measure tends to understate the outputs that are capital-intensive, where presumably much of any effects of IT advances would be concentrated. The BLS index excludes inputs that account for most of the costs, especially interest expenses on the inputs of funds. During the 1984-2001 interval, total wages, salaries, and fringe benefits expenses accounted for only between $15 \%$ and $23 \%$ of bank costs, with the fluctuation over time largely driven by changes in market interest rates, which affect interest expenses.

As well, the focus on transactions, as opposed to intermediation, may not accurately describe the business of banking. Banks are financial intermediaries that transform funds from depositors and other investors into loans and other financial investments. Presumably, intermediating more dollars contributes more to the output of a financial intermediary, even if it is accomplished with the same number of transactions. The

${ }^{21}$ Consistent with this argument, it was noted that the preliminary figures on productivity growth for late 2001 and early 2002 show significant increases, which could reflect the benefits of previous investments in IT that are not significantly confounded by adjustment costs because of the slowdown in investment (Alan Greenspan, Chicago Bank Structure Conference May 10, 2002, reported in Ip 2002). As of this writing, preliminary estimates of nonfarm business labor productivity by the BLS indicate annualized growth rates of 5.5\% and $8.4 \%$ for 2001:Q4 and 2002:Q1, respectively, although the first three quarters of 2001 were much lower, so that the estimate for the full year 2001 is only $1.9 \%$ (http://data.bls.gov/servlet/SurveyOutputServlet?data tool=latest_numbers\&series id=PRS85006092).

${ }^{22}$ See Kunze, Jablonski, and Sieling (1998) and U.S. Bureau of Labor Statistics (1998) for more details. 
exclusion of interest expenses also makes it difficult to evaluate banks' productivity gains in intermediation. For example, banks may have substituted higher rates on deposits for real resources used to provide services on these deposits when deposit rates were deregulated in the early 1980s. Such a substitution would not by itself necessarily constitute a productivity decrease.

In addition, the BLS measure does not include all of the labor input. Much of the labor that goes into back-office processing of payments, computer operations, etc. have been moved over time into service bureaus, which are often affiliates of the same bank holding company. As a result, banks might appear to become more productive over time by shifting some of their workers into service bureaus, paying for these labor hours through transfer payments to service bureaus rather than through labor hours pajd directly by the banks, but this shift does not necessarily constitute a real increase in labor productivity. ${ }^{23}$ As well, to the extent that innovations in data processing, payments processing, and other back-office technologies occur in the service bureaus, they may not be incorporated as measured improvements in commercial bank productivity. ${ }^{24}$

\section{Econometric studies linking technological progress to productivity growth in banking}

The econometric studies of bank productivity address some of these difficulties. The most common methodology uses multiproduct cost functions with detailed variables collected at the individual bank level. A typical (log) banking cost function may be written as:

$$
\ln \mathrm{C}=\mathrm{f}(\mathrm{w}, \mathrm{q}, \mathrm{z}, \mathrm{v})+\ln \mathrm{u}+\ln \varepsilon,
$$

where $\ln$ indicates natural $\log$; $\mathrm{C}$ is variable costs; $\mathrm{f}$ is the $(\log )$ cost function embodying the best-practice frontier; w, q, z, and v are exogenous "business conditions" that affect costs - variable input prices, variable output quantities, fixed input and output quantities, and environmental variables, respectively; lnu is an

\footnotetext{
${ }^{23}$ The bank Call Report item for "other noninterest expense," which includes payments to service bureaus, rose from $10.0 \%$ of operating expenses in 1979 to $14.1 \%$ in 1986 to $25.4 \%$ in 1994 , exceeding total wages, salary and fringe benefits costs paid to employees within commercial banks (Berger, Kashyap, and Scalise 1995, Appendix Table A2). The corresponding figure for 2000 is $22.3 \%$.

${ }^{24}$ There are other difficulties in measuring banking services. Researchers disagree on which deposit, loan, and securities accounts should be measured as outputs versus inputs. As well, banking services are often priced implicitly through below-market interest rates on deposit balances or through higher fees or interest on other services that are part of the customer-bank relationship, making it difficult to value outputs and inputs. For a review of the general difficulties in measuring output in the service sectors, see the NBER volume edited by Griliches (1992), and for more details on issues particular to banking, see the contributions by Berger and Humphrey (1992a), Fixler and Zieschang (1992), Hancock (1992), Triplett (1992), and Wykoff (1992).
} 
inefficiency factor that is zero for best-practice firms and positive for other firms, and ln $\varepsilon$ is mean-zero random error. As shown in Berger and Mester (forthcoming), the predicted gross change in cost at the mean values of all the exogenous factors between period $t$ and $t+1$ may be represented as:

$$
\hat{\mathrm{C}}_{\mathrm{t}+1} / \hat{\mathrm{C}}_{\mathrm{t}}=\left\{\exp \left[\mathrm{f}_{\mathrm{t}+1}\left(\mathrm{x}_{\mathrm{t}+1}\right)\right] \cdot \exp \left[\ln \mathrm{u}_{\mathrm{t}+1}\right]\right\} /\left\{\exp \left[\mathrm{f}_{\mathrm{t}}\left(\mathrm{x}_{\mathrm{t}}\right)\right] \cdot \exp \left[\ln \mathrm{u}_{\mathrm{t}}\right]\right\}
$$

where $\mathrm{x}$ denotes the vector of business conditions ( $\mathrm{w}, \mathrm{q}, \mathrm{z}, \mathrm{v})$ and the subscript $\mathrm{t}$ denotes the cost function or the mean value for a set of variables at time t. The random error ln $\varepsilon$ drops out because it is assumed to be mean zero each period. The predicted gross change in costs is decomposed into three multiplicative terms representing 1) the movement of the best-practice frontier, 2) the change in industry inefficiency or average dispersion from the frontier, and 3) the effect of changes in business conditions:

$$
\begin{aligned}
& \hat{\mathrm{C}}_{\mathrm{t}+1} / \hat{\mathrm{C}}_{\mathrm{t}}=\left\{\exp \left[\mathrm{f}_{\mathrm{t}+1}\left(\mathrm{x}_{\mathrm{t}}\right)\right] / \exp \left[\mathrm{f}_{\mathrm{t}}\left(\mathrm{x}_{\mathrm{t}}\right)\right]\right\} \bullet \text { (Movement of best-practice frontier) } \\
& \left\{\exp \left[\operatorname{lnu}_{\mathrm{t}+1}\right] / \exp [\operatorname{lnu} \mathrm{t}]\right\} \bullet \quad(\text { Change in inefficiency) } \\
& \left\{\exp \left[\mathrm{f}_{\mathrm{t}+1}\left(\mathrm{x}_{\mathrm{t}+1}\right)\right] / \exp \left[\mathrm{f}_{\mathrm{t}+1}\left(\mathrm{x}_{\mathrm{t}}\right)\right] \quad \text { (Changes in business conditions }\right)
\end{aligned}
$$

The movement of the best-practice frontier incorporates technological change and the extent to which the bestpractice firms adopt it. Changes in inefficiency measure the changes in dispersion from best practices, and the change in business conditions is the effect of the changes between periods in input prices, output quantities, fixed netputs, and environmental conditions. The change in cost productivity is measured by the product of the movement in the best-practice frontier and the change in inefficiency, or the first two terms above:

$$
\operatorname{PRODC}_{\mathrm{t}, \mathrm{t}+1}=\left\{\exp \left[\mathrm{f}_{\mathrm{t}+1}\left(\mathrm{x}_{\mathrm{t}}\right)\right] / \exp \left[\mathrm{f}_{\mathrm{t}}\left(\mathrm{x}_{\mathrm{t}}\right)\right]\right\} \bullet\left\{\exp \left[\ln \mathrm{u}_{\mathrm{t}+1}\right] / \exp \left[\ln \mathrm{u}_{\mathrm{t}}\right]\right\}
$$

Thus, cost productivity is the change in predicted costs due to movement of the best-practice frontier and changes in inefficiency, abstracting from random error and changes in exogenous business conditions. This is a gross measure of the increase in costs due to productivity change, so a finding of $\operatorname{PRODC}_{t, t+1}=0.95$ would indicate a $5 \%$ improvement in cost productivity.

The cost function approach addresses a number of problems in the government measures. It accounts for financial market activities of banks, including off-balance sheet activities in the outputs. It also incorporates both financial and nonfinancial inputs, inclusive of interest expenses for financial inputs and 
payments to service bureaus. The cost function approach also statistically removes the effects of exogenous business conditions, so that changes in costs due to changes in market conditions are not attributed to technological progress. A cost function also allows the individual inputs and outputs to contribute to the measurement of productivity in a nonarbitrary way, letting the data "decide" on their relative contributions to value. $\mathrm{PRODC}_{\mathrm{t}, \mathrm{t}+1}$ is also a multifactor productivity measure, rather than a labor productivity measure. Banks are financial intermediaries and their major cost item is the cost of funds, rather than labor compensation.

A number of studies measured productivity growth for U.S. banks during the 1980s and in some cases through 1993, splitting it into movements of the best-practice frontier and changes in inefficiency using either cost productivity (e.g., Berger and Humphrey 1992a, Bauer, Berger, and Humphrey 1993, Berger and Mester forthcoming gr linear programming methods (e.g., Wheelock and Wilson 1999, Devaney and Weber 2000, Alam 2001). ${ }^{25}$ Although these studies are not fully consistent, a general finding was that bank productivity growth $y$ as poor or negative during the early 1980s and may have improved during the late 1980s and early 1990 s. $^{26}$ The unfavorable changes in the early 1980s primarily occurred through shifts in the best-practice frontier, although in some cases, changes in inefficiency were larger (e.g., Wheelock and Wilson 1999, Berger and Mester forthcoming). These studies also often found that bank business conditions deteriorated substantially during the early 1980 s.

The primary driving force behind poor results during the early 1980s appears to be adjustment to industry deregulation, rather than technological change. There was substantial deregulation in the U.S. during this period, including deregulation of deposit rates, liberalization of gharter policy, and reductions in geographic restrictions on banking within states and across state lines. ${ }^{27}$ The deregulation brought about substantial increases in competition, which benefited customers but hurt the measured productivity of the industry. The deregulation of deposit rates and other increases in competition caused bank interest expenses to rise. In part, this was substitution of interest expenses for labor expenses by freeing banks to choose the

\footnotetext{
${ }^{25}$ Linear programming methods relate quantities of outputs to inputs in nonparametric, nonstochastic models. These methods have a number of the same advantages of cost productivity - specifying outputs and inputs in a nonarbitrary way, controlling for exogenous business conditions, separating movements of the best-practice frontier from changes in inefficiency over time, etc.

${ }^{26}$ One study of 1980s bank performance using a profit function found that the profit increases in the latter part of the decade were primarily due to improvements in business conditions, rather than productivity (Humphrey and Pulley 1997).

${ }^{27}$ For more discussion of the deregulation and its effects, see Keeley (1990) and Berger, Kashyap, and Scalise (1995).
} 
optimal mix between interest payments and service, and in part this was higher rates to compete for customers. Banks also expanded their ATM networks with little or no charge to customers. To the extent that the industry performed more poorly because of an increase in competitiveness that raised deposit rates and increased bank spending on ATMs, this may be a social good, because the benefits to depositors may outweigh the higher costs to banks. Thus, the adoption of a highly-valued technological advance, the ATM network, may appear in the data as a reduction in measured productivity, but in fact it likely raised actual productivity.

The finding of poor productivity growth in the early 1980s by the research studies stands in stark contrast to the increases in the BLS labor productivity measure for this period. As noted, the research measures likely understate the productivity gains during this unusual period because they do not account for the transfers to consumers from increased competition. The BLS measure may understate or overstate the productivity growth. Like the research studies, the BLS measure does not account for the transfers to consumers. The BLS measure also excludes gains from the increased output of financial market products, and so could further understate productivity gains. However, the BLS measure may also overstate productivity gains by counting any substitution of interest expenses for labor expenses that likely occurred as gains. As well, the BLS measure counts as a productivity increase when labor is moved into service bureaus, which occurred during the early 1980s. The data suggest that the overstatements may dominate the understatements.

Two recent studies applied the cost productivity methodology to more recent data on U.S. banks from 1991 to 1997. One found small cost productivity improvements of less than 1\% annually (Stiroh 2000), and the other found cost productivity declines of $12.5 \%$ annually for this period, primarily reflecting a significant unfavorable shift in the best-practice frontier (Berger and Mester forthcoming). The studies both found that total costs rose over the 1991-1997 period, but decomposed these differently between productivity growth and changes in "business conditions," or the $\mathrm{x}$ variables (w, q, z, v) shown in the cost function above. The studies employed similar specifications of outputs and inputs, but only the latter study included environment variables (v), which likely explains most of the difference in results. Some of these variables, such as local market nonperforming loans and state income growth, were generally improving over the period and likely improved bank performance in a number of ways, including fewer costs expended dealing with problem loans.

It may be a matter of taste as to whether market conditions that are largely exogenous to any one bank should be included or excluded from measured productivity growth, but it is clear that the extent to which 
researchers control for these conditions can make a substantial difference to measured productivity growth. It might also be argued that to examine the effects of technological progress in particular, it may be better to control for more exogenous business conditions that are not directly related to technological change.

It remains to be explained why costs increased somewhat and at least by one measure, cost productivity declined dramatically during this period of the 1990s when it seems likely that technological progress would have increased productivity. The answer may lie in unmeasured improvements in service quality and variety. Using the same specification of business condition variables, Berger and Mester (forthcoming) found that profit productivity improved by between $13.7 \%$ and $16.5 \%$ annually during the 1991-1997 period even while cost productivity declined by $12.5 \%$ annually. Profit productivity includes revenues as well as costs and is estimated using a profit function in place of a cost function. Profit productivity may be superior to cost productivity because profit maximization more completely describes the economic goals of managers and owners, who take revenues into account as well as costs. An additional benefit is that changes in profits include to some degree unmeasured changes in service quality and variety to the extent that customers pay for these improvements above and beyond the costs of providing the improved quality and variety.

The cost and profit productivity findings are consistent with the hypothesis that over time, banks have provided an improved array of services (e.g., mutual funds, derivatives, on-line services, etc.) that increased bank costs, but were able to raise revenues to more than cover these costs. The small business credit scoring (SBCS) technology discussed above may have also raised both costs and revenues, as banks extended loans to more costly "marginal applicants," but charged them higher loan rates. As argued above, to the extent that markets are competitive, the benefits from these improvements may be competed away, and so this hypothesis requires the presence of market power. The finding of continued increases in profit productivity over time suggests that banks may have retained some market power over these innovations over time until other banks have been able to fully adopt them. For example, adoption of SBCS took a number of years even for large banks, even though the product was franchised and seemingly relatively easy to adopt.

Some additional banking research has looked directly at IT investments and use based on a survey of retail banking practices conducted in 1993 and 1994 by the Wharton Financial Institutions Center. Respondents included most of the large U.S. banks and holding companies, covering over $75 \%$ of industry assets. Several studies were conducted matching the survey data to the bank Call Report. The studies were 
performed on a cross-section basis comparing efficiency of individual institutions because of the one-time nature of the data. Nonetheless, the findings may be useful for assessing the effects of IT investments on productivity growth. Presumably, if IT investment increases productivity over time, the firms that invest the most in IT will have superior efficiency at any point in time - i.e., be close to the best-practice frontier.

The findings from these studies, some of which are summarized in Frei, Harker, and Hunter (2000), do not suggest that IT investment by itself increases efficiency - banks that invested more in IT equipment were not significantly more efficient. However, an important efficiency source may be in the proper use of the equipment. The authors found that investment in IT labor - employees that specialize in IT hardware or software - is efficiency increasing. It is also possible that most of the productivity gains from IT investment may have occurred after the sample period in the mid- and late 1990s, when productivity gains became apparent in the rest of the economy.

\section{Technological progress and the structure of the banking industry}

Technological progress may also affect industry structure, facilitating consolidation by making it more efficient or less inefficient at the margin for banks to be larger, more geographically dispersed, and/or to engage in M\&A activity. These arguments do not imply that it is efficient to have a highly consolidated industry - just that at the margin, there may be more economies or fewer diseconomies to consolidation due to technological advances. Of course, it is also theoretically possible that technological changes may deter consolidation, but in the interest of brevity, we focus only on the more likely case in which consolidation if facilitated. We also focus only on commercial banking, and do not discuss potential economies created to form universal banks that combine banking with other services.

\section{A. Technological progress and banking organization size}

Technological progress may facilitate increases in bank size in at least four different ways. First, it may create new services that are subject to more scale economies or fewer diseconomies than traditional services. For example, IT-driven innovations for delivering depositor services, such as call centers, ATMs, and Internet banking, may exhibit greater economies or less diseconomies of scale than traditional branching networks (Radecki, Wenninger, and Orlow 1997). Similarly, some wholesale products that are financial technology-driven, such as securitization, derivatives, and other off-balance activities may be more efficiently provided at the margin by large banks, consistent with the dominance of large banks in these products. 
Second, technological progress may create new technologies for producing existing banking services that are subject to greater scale economies or fewer diseconomies than the technologies they replace. As discussed above, newer electronic payments processing technologies may have increased scale economies due to IT innovations. Similarly, credit scoring may be characterized by greater scale economies or fewer diseconomies than the lending technologies it replaces. This may be most likely when credit scoring supplants relationship lending, which may be most efficiently provided by small institutions.

Third, technolpgical progress may allow large banks to push out their risk-expected return frontiers more than small banks. ${ }^{28}$ Any scale economies in new risk management systems may help large banks control risks more than small banks. This may expand or create advantages for large banks to make high risk-high expected return investments, improve access to uninsured funding, and/or economize on costly equity capital.

Fourth, technological progress may reduce managerial diseconomies of scale. IT advances may improve monitoring and control within large banks more than within small banks. These technologies may make it easier for managers of large banks to monitor the behavior of their staff, reducing agency problems and better aligning incentives within the bank. New technologies may also help spot operational problems and keep track of the profits and risks associated with different operations. In addition, many of the advances in financial technologies are based more on "hard" quantifiable and verifiable information that may be easier for the management of large organizations to track. To the extent that new products of financial engineering, such as derivative contracts or loans based on credit scores, are more the provinces of large banks, they may improve their monitoring of performance more than small banks.

Turning to the empirical evidence, research on bank cost scale efficiency using data on U.S. banks from the 1980s generally found that the average cost curve had a relatively flat U-shape. Even for small banks, the measured inefficiencies were usually relatively small, on the order of 5\% of costs or less (e.g., Hunter and Timme 1986, Berger, Hanweck, and Humphrey 1987, Noulas, Miller, and Ray 1990, Clark 1996). Some

\footnotetext{
${ }^{28}$ The risk-expected return frontier may be quite important in banking, although idiosyncratic risk is generally not considered to be important in corporate finance, as investors can diversify away this risk. Banks are prudentially regulated and supervised and may bear substantial costs if risk is found to be unacceptably high. As well, bank owners may be risk averse by choice because the costs of financial distress/bankruptcy may be high, the loss of franchise value may be costly, and/or the owners of the bank may not be well diversified (particularly for small, closely held banks). Some evidence suggests that even very largest banking organizations behave as if they are risk averse, trading off between risk and expected returns (e.g., Hughes, Lang, Mester, and Moon 1996, Hughes and Mester 1998).
} 
research using data from the early and mid-1990s suggests that there may be more substantial scale efficiency gains from larger sizes in the 1990s than in the 1980s and that these economies may have continued increasing during the 1990s (e.g., Berger and Mester 1997, Stiroh 2000).

Technological progress may also be reflected in improved revenue scale efficiencies. This may occur if technological change creates new services or improved quality that increase revenues or if the technological change improves the risk-expected return frontier and banks take some of the benefits in higher expected returns. One study of U.S. bank revenue scale efficiency found slight scale efficiencies on the order of $1 \%$ to 4\% of revenues in 1984, but these efficiencies were dissipated by 1990 (Berger, Humphrey, and Pulley 1996). Some research has examined profit efficiency, which includes both costs and revenues. The effects of scale on bank profit efficiency are ambiguous, with profit efficiency sometimes being highest for large banks (Berger, Hancock, and Humphrey 1993), sometimes being highest for small banks (Berger and Mester 1997), and sometimes about equal for large and small banks (Clark and Siems 1997).

Some studies also found a superior risk-expected return frontier for large banks relative to small banks. One early study found scale efficiency from diversification of loan risk as bank loan portfolio sizes increased up to about $\$ 1$ billion (McAllister and McManus 1993). Others found that higher ratios of equity capital are associated with greater resources devoted to managing risks, and that these resource costs are lower for the largest U.S. banking organizations, consistent with scale efficiency (e.g., Hughes, Lang, Mester, and Moon 1996, Hughes and Mester 1998). Other research found that large institutions take the benefits of an improved risk-expected return frontier primarily in higher expected returns by increasing risky loans and reducing equity ratios (e.g., Demsetz and Strahan 1997).

One study examined changes over time in the ability of the senior managers of a multibank holding company (MBHC) to control their affiliate banks by measuring the extent to which the efficiency rank of a nonlead bank affiliate varies with the efficiency rank of the lead bank (the largest bank in the MBHC). The increases in control based on profit efficiency ranks over time were statistically and economically significant, and increased on the order of $50 \%$ to $100 \%$ over the period 1984-1998, consistent with the hypothesis that technological progress has reduced managerial diseconomies of scale (Berger and DeYoung 2002).

\section{B. Technological progress and the geographic expansion of banking organizations}

Technological progress may also facilitate the geographic expansion of banking organizations beyond 
the effects of the increases in bank scale associated with the expansion. First, some new services created by technological progress may be delivered with fewer distance-related diseconomies than traditional services. For example, customers do not need to be geographically proximate to receive services over the Internet or to purchase financial derivatives, and the bank's cost of providing these services does not vary much with distance, in contrast to traditional cash management and relationship-based services.

Second, new technologies may deliver some traditional banking services with fewer distance-related diseconomies. As noted above, ACH data was moved from the physical delivery of computer tapes to electronic delivery, reducing costs associated with distance. As well, credit scoring does not require geographic proximity or local knowledge to screen a potential loan applicant the way that the relationship lending does, and may be provided at greater distances with little or no additional cost.

Third, changes in lending technologies and innovations in risk management technologies may allow banks to monitor and control risk exposures at long distances at less cost. As examples, banks' abilities to observe deteriorations in the quality of loans issued in other nations and to model country risks may have improved over time, allowing them to issue credits at greater distances with less additional cost and risk.

Fourth, technological progress may reduce managerial diseconomies of distance. Similar to the arguments above regarding managerial diseconomies of scale, improvements in IT and financial technologies may make it easier for bank managers to improve monitoring and control over more distant staff.

A number of recent empirical studies found that U.S. banks have been increasing the distances at which they make small business loans (e.g., Cyrnak and Hannan 2000, Petersen and Rajan 2002, Wolken and Rohde 2002), although one study found very little change in distance between small firms and their lender in Belgium (Degryse and Ongena 2002). One study also examined the effects of distance on the efficiency of bank holding company affiliates over time. It found that the negative effect on efficiency of the distance between a nonlead bank and the lead bank in a U.S. MBHC were slightly lessening over time from 1985-1998 (Berger and DeYoung 2002). The greater ability to lend over distances and the slightly lessening negative effect of distance on bank efficiency in the U.S. are consistent with at least slightly reduced distance-related 
diseconomies due to technological progress. ${ }^{29}$

\section{Technological progress and the consolidation process}

Technological progress may also facilitate the consolidation process itself by helping banks engaged in M\&As improve X-efficiency -i.e., move them closer to the best-practice frontier - or reduce the X-efficiency losses associated with an M\&A. First, new banking products created by technological progress may create opportunities for efficiency improvements through the faster spread of new products through consolidation. For example, a bank that operates a transactional Internet website may bring this technology to a bank it acquires and raise the X-efficiency of the institution.

Second, banks may achieve a faster spread of new efficiency-increasing technologies for producing traditional banking services through M\&As. For example, a bank that employs SBCS may apply this technology to some of the loan applications of an acquired bank, or a bank using advanced risk management techniques may apply these to the acquired bank's portfolio.

Third, improvements in IT and financial models may make it easier for acquiring institutions to assess in advance targets that are good candidates for X-efficiency improvements. That is, acquirers may better identify banks that do not offer recently developed services, that do not employ up-to-date technologies in producing traditional services, that are poorly managed, or that have risk profiles that mesh well with the acquiring institution.

Fourth, technological progress may reduce the transition costs and risks associated with M\&As. For example, improved IT and risk management methods may speed the processes of integrating the computer and risk control systems, reducing the costs of integration and the amount of time during which managers may be unaware of developing problems.

The empirical evidence on U.S. bank M\&As using data from the 1980s generally found little or no cost X-efficiency improvement after consolidation. Typically $5 \%$ or less of costs were saved on average,

\footnotetext{
${ }^{29}$ Cross-section studies of the effects of distance on bank performance are mixed. Studies of geographic reach of large banking organizations in the U.S. generally found better risk-expected return frontiers for banks operating in more states (e.g., Hughes, Lang, Mester, and Moon 1996, 1999, Demsetz and Strahan 1997), but a cross-section study of the effects of distance on cost and profit efficiency found slightly negative effects (Berger and DeYoung 2001). Studies of crossborder banking efficiency often found that foreign affiliates operate less efficiently than domestic banks (e.g., DeYoung and Nolle 1996, Berger, DeYoung, Genay, and Udell 2000), but this may be due to international barriers other than distance, such as differences in language, culture, currency, and regulatory/supervisory structures (e.g., Buch 2001).
} 
although some M\&As yielded substantial gains and others yielded substantial losses (e.g., Berger and Humphrey 1992b, Rhoades 1993, DeYoung 1997, Peristiani 1997). The studies using U.S. data from the early 1990s were mixed. As examples, one study of M\&As of large U.S. institutions found modest cost X-efficiency gains (Rhoades 1998), while another study found very little improvement in cost X-efficiency for M\&As of either large or small banks (Berger 1998). Studies of European M\&As also give mixed cost efficiency findings (e.g., Vander Vennet 1996, Resti 1998, Haynes and Thompson 1999).

Profit efficiency studies of U.S. bank M\&As from the 1980s and early 1990s found that M\&As improved profit efficiency, and that this improvement could be linked to improved diversification of risks (Akhavein, Berger, and Humphrey 1997, Berger 1998). After consolidation, banks shifted their portfolios from securities to loans, had lower equity ratios, and more uninsured purchased funds raised at reduced rates. Studies using similar measures found consistent results (e.g., Fixler and Zieschang 1993, Hughes, Lang, Mester, and Moon 1999). These findings are consistent with the hypothesis that an improvement in portfolio diversification allowed institutions to make additional high risk-high expected return investments without additional equity. The study above that found that profit productivity increased while cost productivity declined during the 1990s also found that banks that had recently merged appeared to be responsible for much of the findings (Berger and Mester forthcoming). This is consistent with the hypothesis that banks involved in M\&As spread the new or improved services from afforded by technological advances to the acquired banks. ${ }^{30}$

\section{Conclusions}

Research on the banking industry provides a wealth of information about technological progress. Banks intensively use modern technologies and the detailed data on this industry allow for investigations of the effects of advances in both IT and financial technologies and in both "front-office" and "back-office" technologies. Banking industry data give opportunities to investigate examples in which individual technological changes can be observed and some of their effects can be measured. The detailed data also allows researchers to link technological progress to productivity and other indicators of performance using

\footnotetext{
${ }^{30}$ Other research has compared financial ratios before and after M\&As or used event study methodology to determine the effects of M\&A announcements on the combined values of the consolidating institutions. In our view, the efficiency research tends to control better for business conditions faced by the banks than both types of studies and isolates the actual, rather than expected effects of consolidation as in the event studies. See Berger, Demsetz, and Strahan (1999) for comparisons of all of these types of studies.
} 
multiproduct cost and profit functions and other methods. These methods help account for improvements in service quality and variety and address other difficulties inherent in the use of labor productivity indexes. The banking data also allow for analysis of the effects of technological progress on banking industry structure - or the extent to which technological progress facilitates consolidation - using statistics on bank scale, distances, and mergers and acquisitions (M\&As).

The raw data on the banking industry show the changes over time in the use of technology, including the shift to IT-based delivery systems like ATMs and Internet banking and the proliferation of financial technologies such as financial derivatives and off-balance sheet credit commitments. The data also show improvements in bank performance and consolidation of the industry during the deployment of new technologies, although establishing the links between technological progress and both banking industry productivity growth and industry structure require multivariate analyses.

The microeconomic research on banking technologies also yields a number of findings. IT advances appear to have increased productivity and scale economies in processing electronic payments that have reduced costs dramatically - in some cases by more than 50\% during the $1990 \mathrm{~s}$ - and may help explain some of the recent shift of customers from paper to electronic payments. The use of the small business credit scoring technology also appears to have yielded benefits by increasing lending to "marginal applicants" that might not otherwise receive bank credit. Notably, this finding required use of special banking data sets with information on loan portfolio composition - i.e., banks using the technology issued more small loans with relatively high interest rates and risky credit ratings than otherwise comparable banks. Such a finding would not be easily captured in conventional output or productivity measures. The evidence on Internet banking is less clear because of the lack of experience with this technology, but it appears the largest U.S. banks that serve the vast majority of customers have adopted this technology, adding transactional Internet sites to existing physical offices and ATM networks. Similar to the experience with ATMs in the early 1980s, competitive pressures may result in customers gaining most or all of the benefits of Internet banking, making it difficult to measure the productivity gains. These examples illustrate the multiplicity of different actual and measured effects of technological progress. The microeconomic research also suggests that 1) most of the important new technologies were generally adopted earlier by large banks than small banks, 2) even small banks can take some advantage of scale economies associated with back-office operations through outsourcing and other 
methods, and 3) the effects of a new technology may vary significantly with how it is implemented.

There are a number of difficulties in linking technological progress to productivity growth, and the econometric studies of bank productivity address some of these difficulties. The BLS labor productivity index for the commercial banking industry showed dramatic productivity growth much earlier than in the economy as a whole - in the early 1980s versus the mid-1990s. The econometric studies, in contrast, generally found that bank productivity growth was poor or negative during the early 1980s and improved in later periods. Both the research measures and the BLS measure may understate the productivity gains during the early 1980s because they do not account for the transfer payments to consumers from increased competition due to deregulation. The BLS measure may also exclude gains from the increased output of financial market products. However, the BLS measure may also overstate productivity gains by counting any substitution of interest expenses for labor expenses and any movement of labor into service bureaus as productivity increases. The data suggest that these overstatements may dominate the understatements.

The research findings for the 1990s suggest that after controlling for exogenous market conditions, bank cost productivity declined but profit productivity improved. These findings are consistent with the hypothesis that technological progress resulted in improved quality and variety of banking services that increased costs, and that customers were willing to pay for these improvements so banks were able to raise revenues sufficiently to more than cover the higher costs.

Technological progress may also have important effects on the structure of an industry, facilitating consolidation by making it more efficient or less inefficient at the margin for firms to be larger, more geographically dispersed, and/or to engage in M\&A activity. The banking data are at least somewhat consistent with all three of these effects. The research suggests that there may be more bank cost scale economies or fewer diseconomies in the 1990s, and that multibank holding companies (MBHCs) significantly improved control over their affiliate banks between the 1980s and 1990s. The research also suggests that banks have been able to make small business loans at greater distances and that affiliate banks suffered fewer diseconomies associated with the distance to MBHC headquarters in recent years. The research on the dynamic effects of M\&As is consistent with the hypothesis that consolidating banks improved their profit efficiency and risk-expected return frontiers, and that acquirers were able to spread the provision of new or improved banking services afforded by technological advances to the targets. 


\section{References}

Akhavein, Jalal D., Allen N. Berger, and David B. Humphrey. "The Effects of Bank Megamergers on Efficiency and Prices: Evidence from the Profit Function." Review of Industrial Organization 12 (February 1997), 95-139.

Akhavein, Jalal, W. Scott Frame, and Lawrence J. White. "The Diffusion of Financial Innovation: An Examination of the Adoption of Small Business Credit Scoring by Large Banking Organizations." Federal Reserve Bank of Atlanta Working Paper 2001-9. 2001.

Alam, Ila M.S. “A Non-Parametric Approach for Assessing Productivity Dynamics of Large Banks.” Journal of Money, Credit, and Banking 33 (February 2001), 121-139.

Allen, Franklin, James McAndrews, and Philip Strahan. "E-Finance: An Introduction.” Journal of Financial Services Research 22 (August 2002), 5-27.

Avery, Robert B., and Allen N. Berger. "Risk-Based Capital and Deposit Insurance Reform.” Journal of Banking and Finance 15 (September 1991), 847-874.

Avery, Robert B., Raphael W. Bostic, Paul S. Calem, and Glenn B. Canner. "Credit Scoring: Statistical Issues and Evidence from Credit-Bureau Files.” Real Estate Economics 28 (Fall 2000), 523-547.

Basu, Susanto, John G. Fernald, and Matthew D. Shapiro. "Productivity Growth in the 1990s: Technology, Utilization, or Adjustment?" Carnegie-Rochester Conference Series on Public Policy 55 (December 2001), 17-65.

Bauer, Paul W., Allen N. Berger, and David B. Humphrey. "Efficiency and Productivity Growth in U.S. Banking," In The Measurement of Productive Efficiency: Techniques and Applications, edited by Harold O. Fried, C.A. Knox Lovell, and Shelton S. Schmidt, pp. 386-413. Oxford: Oxford University Press, 1993.

Bauer, Paul W., and Gary D. Ferrier. "Efficiency Measurement Issues for Payments Processing." Journal of Money, Credit and Banking 28 (November 1996), 1004-1039.

Bauer, Paul W., and Diana Hancock. "Scale Economies and Technical Change in the Federal Reserve Automated Clearinghouse Payment Processing." Federal Reserve Bank of Cleveland Economic Review 33 (Third Quarter 1995), 14-29.

Bauer, Paul W., and Patrick Higgins. "Post Consolidation Estimates of ACH Scale Economies, Technical Change, and Cost Efficiency." Federal Reserve Bank of Cleveland Working paper, 2002.

Benveniste, Lawrence M. and Allen N. Berger. "Securitization With Recourse: An Instrument That Offers Uninsured Bank Depositors Sequential Claims," Journal of Banking and Finance 11 (September 1987), 403-424.

Berger, Allen N. "The Efficiency Effects of Bank Mergers and Acquisition: A Preliminary Look at the 1990s Data." In Bank Mergers \& Acquisitions, edited by Yakov Amihud and Geoffrey Miller, pp. 79-111. Boston: Kluwer Academic, 1998.

Berger, Allen N., Rebecca S. Demsetz, and Philip E. Strahan. 1999. "The Consolidation of the Financial Services Industry: Causes, Consequences, and Implications for the Future.” Journal of Banking and Finance 23 
(February 1999), 135-194.

Berger, Allen N., and Robert DeYoung. "The Effects of Geographic Expansion on Bank Efficiency." Journal of Financial Services Research 19 (April-June 2001), 163-184.

Berger, Allen N., and Robert DeYoung. "Technological Progress and the Geographic Expansion of the Banking Industry.” Federal Reserve Board Finance and Economics Discussion Series 2002-31 (June 2002), http://www.federalreserve.gov/pubs/feds/2002/200231/200231pap.pdf.

Berger, Allen N., Robert DeYoung, Hesna Genay, and Gregory F. Udell. "The Globalization of Financial Institutions: Evidence from Cross-Border Banking Performance." Brookings-Wharton Papers on Financial Services 3 2000, 23-158.

Berger, Allen N., W. Scott Frame, and Nathan H. Miller. "Credit Scoring and the Price and Availability of Small Business Credit." Federal Reserve Board Finance and Economics Discussion Series 2002-26 (June 2002), http://www.federalreserve.gov/pubs/feds/2002/200226/200226pap.pdf.

Berger, Allen N., Diana Hancock, and David B. Humphrey. "Bank Efficiency Derived from the Profit Function." Journal of Banking and Finance 17 (July 1993), 317-347.

Berger, Allen N., Diana Hancock, and Jeffrey C. Marquardt. "A Framework for Analyzing Efficiency, Risks, Costs, and Innovations in the Payments System." Journal of Money, Credit and Banking 28 (November 1996), 696-732.

Berger, Allen N., Gerald A. Hanweck, and David B. Humphrey. "Competitive Viability in Banking: Scale, Scope, and Product Mix Economies,” Journal of Monetary Economics 20 (December 1987), 501-520.

Berger, Allen N., and David B. Humphrey. "Measurement and Efficiency Issues in Commercial Banking." In Output Measurement in the Service Sectors, edited by Zvi Griliches, pp. 245-79. National Bureau of Economic Research Studies in Income and Wealth 56. University of Chicago Press, 1992a.

Berger, Allen N., and David B. Humphrey. "Megamergers in Banking and the Use of Cost Efficiency as an Antitrust Defense." Antitrust Bulletin 37 (Fall 1992), 541-600 (b).

Berger, Allen N., David B. Humphrey, and Lawrence B. Pulley. "Do Consumers Pay for One-Stop Banking? Evidence from an Alternative Revenue Function," Journal of Banking and Finance 20 (1996), 1601-21.

Berger, Allen N., Anil K Kashyap, and Joseph M. Scalise. "The Transformation of the U.S. Banking Industry: What a Long, Strange Trip It's Been.” Brookings Papers on Economic Activity (1995:2), 55-201.

Berger, Allen N., and Loretta J. Mester. "Inside the Black Box: What Explains Differences in the Efficiencies of Financial Institutions?” Journal of Banking and Finance 21 (July 1997), 895-947.

Berger, Allen N., and Loretta J. Mester. "Explaining the Dramatic Changes in the Performance of U.S. Banks: Technological Change, Deregulation, and Dynamic Changes in Competition," Journal of Financial Intermediation, forthcoming.

Berger, Allen N., and Gregory F. Udell. "Securitization, Risk, and the Liquidity Problem in Banking." In Structural Change in Banking, edited by Michael Klausner and Lawrence J. White, pp. 227-291. Irwin (Richard D.), Homewood, IL, 1993. 
Bohn, James, Diana Hancock, and Paul Bauer. "Estimates of Scale and Cost Efficiency for Federal Reserve Currency Operations." Federal Reserve Bank of Cleveland Economic Review 37 (Quarter 4, 2001), 226.

Boskin, Michael J., Ellen R. Dulberger, Robert J. Gordon, Zvi Griliches, and Dale Jorgenson . "Toward a More Accurate Measure of the Cost of Living", final report to the Senate Finance Committee from the Advisory Commission To Study the Consumer Price Index, 1996. http://www.ssa.gov/history/reports/boskinrpt.html,

Buch, Claudia M. "Distance and International Banking." Kiel Institute of World Economics, Kiel Working Paper No. 1043, 2001.

Claessens, Stijn, Thomas Glaessner, and Daniela Klingebiel. "Electronic Finance: Reshaping the Financial Landscape Around the World." Journal of Financial Services Research 22 (August 2002), 29-61.

Clark, Jeffrey A. "Economic Cost, Scale Efficiency and Competitive Viability in Banking." Journal of Money, Credit, and Banking, 28 (August 1996), 342-64.

Clark, Jeffrey A., and Thomas F. Siems. "Competitive Viability in Banking: Looking beyond the Balance Sheet," Financial Industry Studies Working Paper 97-5. Federal Reserve Bank of Dallas, 1997.

Corvoisier, Sandrine, and Reint Gropp. "Contestability, Technology and Banking, European Central Bank working paper, 2001.

Courchane, Marsha, David Nickerson, and Richard Sullivan. "Financial Innovation, Strategic Real Options and Endogenous Competition: Theory and an Application to Internet Banking," Colorado State University working paper, 2002.

Cyrnak, Anthony W., and Timothy H. Hannan. "Non-Local Lending to Small Businesses," Federal Reserve Board working paper, 2000.

Degryse, Hans, and Steven Ongena. "Distance, Lending Relationships, and Competition," University of Tilburg working paper, 2002.

Demsetz, Rebecca S. and Philip E. Strahan. "Diversification, Size, and Risk at Bank Holding Companies." Journal of Money, Credit, and Banking 29 (August 1997), 300-13.

Devaney, Michael, and Warren Weber. "Productivity Growth, Market Structure, and Technological Change: Evidence from the Rural Banking Sector," Applied Financial Economics 10 (December 2000), 587-595.

DeYoung, Robert. "Bank Mergers, X-Efficiency, and the Market for Corporate Control." Managerial Finance 23 (February 1997), 32-47.

DeYoung, Robert. "Learning-by-Doing, Scale Efficiencies, and Financial Performance at Internet-Only Banks," Federal Reserve Bank of Chicago Working Paper 01-06 (updated, June 2002).

DeYoung, Robert, and Daniel E. Nolle. "Foreign-Owned Banks in the U.S.: Earning Market Share or Buying It?" Journal of Money, Credit, and Banking 28 (November 1996), 622-636.

Fixler, Dennis and Kimberly Zieschang. "User Cost, Shadow Prices, and the Real Output of Banks," In Output Measurement in the Service Sectors, edited by Zvi Griliches, pp. 219-243. National Bureau of Economic 
Research Studies in Income and Wealth 56. University of Chicago Press, 1992.

Fixler, Dennis and Kimberly Zieschang. "An Index Number Approach to Measuring Bank Efficiency: An Application to Mergers." Journal of Banking and Finance 17 (April 1993), 437-450.

Frame, W. Scott, Michael Padhi, and Lynn Woolsey. "The Effect of Credit Scoring on Small Business Lending in Low- and Moderate Income Areas.” Federal Reserve Bank of Atlanta Working Paper 2001-6.

Frame, W. Scott, Aruna Srinivasan, and Lynn Woosley. "The Effect of Credit Scoring on Small Business Lending." Journal of Money, Credit, and Banking, 33 (August 2001), 813-825.

Frame, W. Scott and Lawrence J. White. "Empirical Studies of Financial Innovation: Lots of Talk, Little Action?" Federal Reserve Bank of Atlanta working paper, 2002.

Frei, Frances X., Patrick T. Harker, Larry W. Hunter. “Inside the Black Box: What Makes a Bank Efficient?” in Performance of Financial Institutions: Efficiency, Innovation, Regulation, edited by Patrick T. Harker and Stavros A. Zenios, pp. 259-311. Cambridge University Press, Cambridge, UK., 2000.

Furlong, Fred. "Productivity in Banking." Federal Reserve Bank of San Francisco, Economic Letter 2001-22, (July 2001).

Furst, Karen, William W. Lang, and Daniel E. Nolle. "Internet Banking in the U.S.: Landscape, Prospects, and Industry Implications," Journal of Financial Transformation, The Capco Institute, 2, 45-52, 2001.

Furst, Karen, William W. Lang, and Daniel E. Nolle. "Internet Banking.” Journal of Financial Services Research 22 (August 2002), 95-117.

Gerdes, Geoffrey R., and Jack K. Walton II. "The Use of Checks and Other Retail Noncash Payments in the United States," Federal Reserve Bulletin (August 2002), 360-374.

Gilbert, R. Alton, David C. Wheelock, and Paul W. Wilson. "New Evidence on the Fed's Productivity in Providing Payments Services.” Federal Reserve Bank of St. Louis working paper, 2002.

Gordy, Michael B. "A Comparative Anatomy of Credit Risk Models." Journal of Banking and Finance 24 (January 2000), 119-149.

Gowrisankaran, Gautam, and Joanna Stavins. "Network Externalities and Technology Adoption: Lessons from Electronic Payments.” Federal Reserve Bank of San Francisco working paper, 2002.

Griliches, Zvi, editor. Output Measurement in the Service Sectors, National Bureau of Economic Research Studies in Income and Wealth 56. University of Chicago Press, 1992.

Hancock, Diana. "Comment." In Output Measurement in the Service Sectors, edited by Zvi Griliches, pp. 296300. National Bureau of Economic Research Studies in Income and Wealth 56. University of Chicago Press.

Hancock, Diana, and David B. Humphrey. "Payment Transactions, Instruments, and Systems: A Survey." Journal of Banking and Finance 21 (December 1998), 1573-1624.

Hancock, Diana, David B. Humphrey, and James A. Wilcox. 1999. "Cost Reductions in Electronic Payments: The Roles of Consolidation, Economies of Scale, and Technical Change.” Journal of Banking and 
Finance 23 (February 1999), 391-421.

Hannan, Timothy H., and John M. McDowell. "The Determinants of Technology Adoption: The Case of the Banking Firm." Rand Journal of Economics 15 (Autumn 1984), 328-335.

Hausman, Jerry A. "New Products and Price Indices." NBER Reporter (Fall 1998), 10-12 http://www.nber.org/reporter/fall98/hausman_fall98.html.

Hauswald, Robert and Robert Marquez. "Information Technology and Financial Services Competition,” Review of Financial Studies, (forthcoming).

Haynes, Michelle, and Steve Thompson. "The Productivity Effects Of Bank Mergers: Evidence From The UK Building Societies.” Journal of Banking and Finance 23 (May 1999), 325-846.

Hughes, Joseph P., William W. Lang, Loretta J. Mester, and Choon-Geol Moon. "Efficient Banking Under Interstate Branching." Journal of Money, Credit, and Banking, 28 (November 1996), 1043-71.

Hughes, Joseph P., William W. Lang, Loretta J. Mester, and Choon-Geol Moon. "The Dollars and Sense of Bank Consolidation.” Journal of Banking and Finance 23 (February 1999), 291-324.

Hughes, Joseph P., and Loretta J. Mester. "Bank Capitalization and Cost: Evidence of Scale Economies in Risk Management and Signaling." Review of Economics and Statistics 80 (May 1998), 314-25.

Humphrey, David B. "U.S. Cash and Card Payments over 25 Years," Working paper, Florida State University, 2002.

Humphrey, David B., and Lawrence B. Pulley. "Banks' Responses to Deregulation: Profits, Technology, and Efficiency." Journal of Money, Credit, and Banking 29 (February 1997), 73-93.

Hunter, William C., and Stephen G. Timme. "Technical Change, Organizational form, and the Structure of Bank Productivity." Journal of Money, Credit and Banking 18 (May 1986), 152-166.

Ip, Greg. “Greenspan Expresses Optimism for Growth of U.S. Economy.” Wall Street Journal (May 13, 2002), A2.

Jappelli, Tullio, and Marco Pagano. "Information Sharing, Lending and Defaults: Cross-Country Evidence." Center for Studies in Economics and Finance working paper 22, University of Salerno (May 1999).

Jagtiani, Julapa, Anthony Saunders, and Gregory F. Udell. "Bank Off-Balance Sheet Financial Innovations and the Role of Capital," Journal of Banking and Finance 19 (April 1995), 647-658.

Jorgenson, Dale W., and Kevin J. Stiroh. "Raising the Speed Limit: US Economic Growth in the Information Age." Brookings Papers on Economic Activity (2000:1), 125-211.

Koppenhaver, Gary D. “The Effects of Regulation on Bank Participation in the Guarantee Market,” In Research in Financial Services: Private and Public Policy, edited by George Kaufman, pp. : 165-180. JAI Press, Inc., Greenwich, Conn., 1989.

Kallberg, Jarl G., and Gregory F. Udell. "The Value of Private Sector Credit Information Sharing: The U.S. Case," Journal of Banking and Finance 26 (2002) (a). 
Kallberg, Jarl G., and Gregory F. Udell. "Private Business Information Exchange in the U.S.," in Credit Reporting Systems and the International Economy edited by Margaret Miller, MIT Press, 2002 (b).

Keeley, Michael C. "Deposit Insurance, Risk, and Market Power in Banking." American Economic Review 80 (December 1990), 1183-200.

Klapper, Leora F. and Elke Kraus. "The Information Infrastructure of South Africa,” World Bank mimeo, 2002.

Kunze, Kent, Mary Jablonski, and Mark Sieling. "Measuring Output and Labor Productivity of Commercial Banks (SIC 602): A Transactions-Based Approach.” Office of Productivity and Technology, Bureau of Labor Statistics, U.S. Department of Labor, 1998.

McAllister, Patrick H., and Douglas A. McManus. "Resolving the Scale Efficiency Puzzle in Banking." Journal of Banking and Finance 17 (April 1993), 389-405.

McKinsey Global Institute. “U.S. Productivity Growth, 1995-2000” (Washington: McKinsey), 2001.

Mester, Loretta J. "What's the Point of Credit Scoring?" Federal Reserve Bank of Philadelphia Business Review, (September/October 1997), 3-16.

Molyneux, Phil and Nidal Shamroukh. "Diffusion of Financial Innovations: The Case of Junk Bonds and Note Issuance Facilities," Journal of Money, Credit, and Banking 28 (August 1996), 502-522.

Noulas, Athanasios G., Stephen M. Miller, and Subhash C. Ray. "Returns to Scale and Input Substitution for Large U.S. Banks.” Journal of Money, Credit, and Banking 22 (February 1990), 94-108.

Oliner, Steven and Daniel Sichel. "The Resurgence of Growth in the Late 1990s: Is Information Technology the Story?” Journal of Economic Perspectives 14 (Fall 2000), 3-22.

Pagano, Marco and Tullio Jappelli. Information Sharing in Credit Markets, Journal of Finance 43 (December 1993), 1693-1718.

Pakes, Ariel. “A Reconsideration of Hedonic Price Indices with an Application to PC's." Working Paper 8715. Cambridge, Mass.: National Bureau of Economic Research (January 2002). http://papers.nber.org/papers/W8715.

Peristiani, Stavros. "Do Mergers Improve the X-efficiency and Scale Efficiency of U.S. banks? Evidence from the 1980s." Journal of Money, Credit, and Banking 29 (August 1997), 326-337.

Petersen, Mitchell A., and Raghuram G. Rajan. "The Information Revolution and Small Business Lending: Does Distance Still Matter?” Journal of Finance (2002).

Radecki, Lawrence J., John Wenninger, and Daniel K. Orlow. "Industry Structure: Electronic Delivery's Potential Effects on Retail Banking.” Journal of Retail Banking Services 19 (Winter 1997), 57-63.

Resti, Andrea. 1998. "Regulation Can Foster Mergers, Can Mergers Foster Efficiency? The Italian Case." Journal of Economics and Business 50 (March-April 1998), 157-169.

Rhoades, Stephen A. 1998. "The Efficiency Effects of Bank Mergers: An Overview of Case Studies of Nine Mergers.” Journal of Banking and Finance 22 (March 1998), 273-291. 
Saloner, Garth, and Andrea Shepard. "Adoption of Technologies with Network Effects: An Empirical Examination of the Adoption of Automated Teller Machines." Rand Journal of Economics 26 (Autumn 1995), 479-501.

Solow, Robert M. "Technical Change and the Aggregate Production Function." Review of Economics and Statistics 39 (1957), 313-330.

Stiroh, Kevin J. “How Did Bank Holding Companies Prosper in the 1990s?” Journal of Banking and Finance 24 (November 2000), 1703-1745.

Stiroh, Kevin J. “Information Technology and the Productivity Revival: What do the Industry Data Say?" Federal Reserve Bank of New York working paper 2001.

Sullivan, Richard. "Performance and Operation of Commercial Bank Web Sites," Federal Reserve Bank of Kansas City, Financial Industry Perspectives (December 2001), 23-33.

Triplett, Jack E. “Comment.” In Output Measurement in the Service Sectors, edited by Zvi Griliches, pp. 287296. National Bureau of Economic Research Studies in Income and Wealth 56. University of Chicago Press, 1992.

Triplett, Jack E., and Barry P. Bosworth, “'Baumol's Disease' has been Cured: IT and Multifactor Productivity in U.S. Services Industries,” Brookings Institution Working Paper, July 2002.

U.S. Bureau of Labor Statistics. Technical Note, Commercial Banks - SIC 602, Output Components and Weights (December 1998).

Vander Vennet, Rudi. "The Effect of Mergers and Acquisitions on the Efficiency and Profitability of EC Credit Institutions." Journal of Banking and Finance 20 (November 1996), 1531-1558.

Wheelock, David C., and Paul W. Wilson. "Technical Progress, Inefficiency, and Productivity Change in U.S. Banking, 1984-1993," Journal of Money, Credit, and Banking 31 (May 1999), 212-234.

Wolken, John, and Douglas Rohde. "Changes in the Location of Small Businesses' Financial Service Suppliers between 1993 and 1998," Federal Reserve Board internal memorandum, 2002.

Wykoff, Frank C. “Comment." In Output Measurement in the Service Sectors, edited by Zvi Griliches, pp. 279287. National Bureau of Economic Research Studies in Income and Wealth 56. University of Chicago Press, 1992. 
Table 1: The Structure of the Banking Industry and the Use of Selected Technologies, 1984-2001. Number of Banking Organizations is the number of top-tier holding companies plus the number of independent commercial banks. Gross Total Assets (GTA) equals total assets plus loan and lease loss reserves and allocated transfer risk reserve (a reserve for certain foreign loans). Local Market Herfindahl Index is the average bank weighted average Herfindahl index of local deposit market concentration across the bank's markets (Metropolitan Statistical Areas \{MSAs\} or non-MSA rural counties), where each weight is the bank's deposit share in the market. Number of Physical Banking Offices generally includes bank head offices, full service branches, and limited service branches with human tellers (varies slightly by state regulator). ATMs is the number of automated teller machines. Credit Commitments includes financial and performance standby letters of credit, commercial and similar letters of credit, total unused commitments, and participations in acceptances. Interest Rate Swaps is the notional value of all outstanding interest rate swaps (not available for 1984). Number of Banking Organizations, Number of Banks, Gross Total Assets (GTA), Physical Banking Offices, Credit Commitments, and Interest Rate Swaps are obtained from the December Reports of Condition and Income (Call Reports). Local Market Herfindahl Index is obtained from the Summary of Deposits. Number of ATMs is obtained from the EFT Data Book. All financial variables are reported in real 1994 dollars, using the GDP deflator.

\begin{tabular}{|c|c|c|c|c|c|c|c|c|}
\hline Year & $\begin{array}{c}\text { Number of } \\
\text { Banking } \\
\text { Organizations }\end{array}$ & $\begin{array}{c}\text { Number of } \\
\text { Banks }\end{array}$ & $\begin{array}{c}\text { Gross Total } \\
\text { Assets (GTA) } \\
\text { (\$ trillions) }\end{array}$ & $\begin{array}{l}\text { Local Market } \\
\text { Herfindahl } \\
\text { Index }\end{array}$ & $\begin{array}{c}\text { Number of } \\
\text { Physical } \\
\text { Banking } \\
\text { Offices } \\
\text { (thousands) }\end{array}$ & $\begin{array}{l}\text { Number of } \\
\text { ATMs } \\
\text { (thousands) }\end{array}$ & $\begin{array}{c}\text { Credit } \\
\text { Commitments } \\
\text { (\$ trillions) }\end{array}$ & $\begin{array}{c}\text { Interest Rate } \\
\text { Swaps } \\
\text { (\$ trillions) }\end{array}$ \\
\hline 1984 & 11,433 & 14,392 & 3.44 & 0.1711 & 50 & 58 & 0.91 & $*$ \\
\hline 1985 & 11,094 & 14,272 & 3.62 & 0.1685 & 51 & 61 & 0.97 & 0.25 \\
\hline 1986 & 10,587 & 14,058 & 3.80 & 0.1673 & 51 & 64 & 0.97 & 0.47 \\
\hline 1987 & 10,196 & 13,561 & 3.78 & 0.1693 & 53 & 68 & 0.99 & 0.89 \\
\hline 1988 & 9,807 & 12,984 & 3.78 & 0.1737 & 54 & 72 & 1.01 & 1.12 \\
\hline 1989 & 9,525 & 12,563 & 3.84 & 0.1762 & 54 & 76 & 1.01 & 1.56 \\
\hline 1990 & 9,284 & 12,202 & 3.77 & 0.1814 & 56 & 80 & 1.46 & 1.89 \\
\hline 1991 & 9,073 & 11,821 & 3.69 & 0.1879 & 57 & 84 & 1.47 & 1.87 \\
\hline 1992 & 8,780 & 11,359 & 3.67 & 0.1928 & 58 & 87 & 1.51 & 2.21 \\
\hline 1993 & 8,366 & 10,874 & 3.78 & 0.1990 & 58 & 95 & 1.64 & 2.99 \\
\hline 1994 & 7,932 & 10,362 & 3.99 & 0.2013 & 59 & 109 & 1.95 & 4.41 \\
\hline 1995 & 7,602 & 9,857 & 4.18 & 0.2023 & 60 & 123 & 2.29 & 5.37 \\
\hline 1996 & 7,335 & 9,448 & 4.35 & 0.2061 & 61 & 139 & 2.61 & 6.72 \\
\hline 1997 & 7,144 & 9,066 & 4.70 & 0.2079 & 62 & 165 & 3.06 & 8.45 \\
\hline 1998 & 6,869 & 8,711 & 5.04 & 0.2080 & 64 & 187 & 3.59 & 12.63 \\
\hline 1999 & 6,747 & 8,510 & 5.20 & 0.2073 & 65 & 227 & 3.73 & 15.40 \\
\hline 2000 & 6,674 & 8,238 & 5.55 & 0.2053 & 67 & 273 & 4.11 & 18.81 \\
\hline 2001 & 6,578 & 8,016 & 5.69 & 0.2050 & 72 & 324 & 4.37 & 21.46 \\
\hline Average & & & & & & & & \\
\hline $\begin{array}{c}\text { Growth } \\
\text { Rate }\end{array}$ & -0.033 & -0.034 & 0.030 & 0.011 & 0.021 & 0.101 & 0.092 & 0.279 \\
\hline
\end{tabular}


Table 2: The Structure of Financial Markets, 1984-2001. Gross Total Assets (GTA) equals total assets plus loan and lease loss reserves and allocated transfer risk reserve (a reserve for certain foreign loans). Money Market Mutual Fund Shares includes money market mutual fund shares held by the household sector, nonfinancial corporate business, nonfarm noncorporate business, and the financial sector. Corporate Equity at Market Value includes equity issued by nonfinancial corporate business and financial corporations, and excludes mutual fund shares. Corporate Bonds and Commercial Paper include corporate bonds and commercial paper issued by nonfinancial corporate business and financial sectors (excluding holdings of foreign issues by U.S. residents). Mortgage Pools and Other Asset-Backed Securities include federally related mortgage pools, private mortgage pools (home, multifamily residential, and commercial), and pools of agency securities, consumer credit, trade receivables, student loans and loans to business. GTA is obtained from the December Reports of Condition and Income (Call Reports). Money Market Mutual Fund Shares, Corporate Equity at Market Value, Corporate Bonds and Commercial Paper, and Mortgage Pools and Other Asset-Backed Securities, are obtained from the Flow of Funds. All numbers are reported in trillions of real 1994 dollars, using the GDP deflator.

\begin{tabular}{|cccccc|}
\hline Year & $\begin{array}{c}\text { Bank } \\
\text { Gross Total Assets } \\
\text { (GTA) } \\
\text { (\$ trillions) }\end{array}$ & $\begin{array}{c}\text { Money Market } \\
\text { Mutual Fund Shares, } \\
\text { Total Assets } \\
\text { (\$ trillions) }\end{array}$ & $\begin{array}{c}\text { Corporate Equity at } \\
\text { Market Value } \\
\text { (\$ trillions) }\end{array}$ & $\begin{array}{c}\text { Corporate Bonds and Mortgage Pools and } \\
\text { Commercial Paper } \\
\text { (\$ trillions) }\end{array}$ & $\begin{array}{c}\text { Other Asset-Backed } \\
\text { Securities, } \\
\text { Total Assets } \\
\text { (\$ trillions) }\end{array}$ \\
\hline 1984 & & & & & \\
1985 & 3.44 & 0.32 & 2.44 & 0.95 & 0.42 \\
1986 & 3.62 & 0.32 & 3.00 & 1.14 & 0.54 \\
1987 & 3.80 & 0.37 & 3.46 & 1.38 & 0.78 \\
1988 & 3.78 & 0.39 & 3.38 & 1.58 & 0.98 \\
1989 & 3.78 & 0.40 & 3.69 & 1.81 & 1.08 \\
1990 & 3.84 & 0.49 & 4.41 & 2.00 & 1.25 \\
1991 & 3.77 & 0.54 & 3.91 & 2.12 & 1.60 \\
1992 & 3.69 & 0.57 & 5.19 & 2.24 & 1.75 \\
1993 & 3.67 & 0.56 & 5.65 & 2.42 & 2.88 \\
1994 & 3.78 & 0.57 & 6.39 & 2.63 & 2.02 \\
1995 & 3.99 & 0.60 & 6.27 & 2.84 & 2.44 \\
1996 & 4.18 & 0.72 & 8.20 & 3.19 & 2.71 \\
1997 & 4.35 & 0.84 & 9.78 & 3.58 & 3.16 \\
1998 & 4.70 & 0.98 & 12.47 & 4.09 & 3.56 \\
1999 & 5.04 & 1.24 & 14.48 & 4.81 & 3.88 \\
2000 & 5.20 & 1.44 & 17.86 & 5.47 & \\
2001 & 5.55 & 1.63 & 15.81 & 6.03 & \\
& 5.69 & 1.97 & 13.38 & 6.53 & \\
Average & & & & & \\
Growth & 0.030 & 0.108 & 0.100 & 0.113 & \\
Rate & & & & & \\
\hline
\end{tabular}


Table 3: The Performance of the Banking Industry, 1984-2001. Return on Equity is net income divided by the average of this year's and the previous year's total equity capital. Return on GTA is net income divide by total assets plus loan and lease loss reserves and allocated transfer risk reserve (a reserve for certain foreign loans). Total Costs / GTA is total expenses (interest expense $\mathbf{s}+$ noninterest expenses) divided by total assets plus loan and lease loss reserves and allocated transfer risk reserve. Noninterest Expenses / GTA is total noninterest expenses divided by total assets plus loan and lease loss reserves and allocated transfer risk reserve. Interest Expenses / GTA is total interest expenses divided by total assets plus loan and lease loss reserves and allocated transfer risk reserve. Revenues / Total Costs is operating income divided by total costs. NPL / Loans is nonperforming loans (either past due at least 30 days or on nonaccrual basis) divided by total loans. Ratios are weighted averages, using the denominators as relative weights. All data are obtained from the December Reports of Condition and Income (Call Reports).

\begin{tabular}{|cccccccc|}
\hline Year & $\begin{array}{c}\text { Return on } \\
\text { Equity }\end{array}$ & $\begin{array}{c}\text { Return on } \\
\text { GTA }\end{array}$ & $\begin{array}{c}\text { Total Costs / } \\
\text { GTA }\end{array}$ & $\begin{array}{c}\text { Noninterest } \\
\text { Expenses / GTA }\end{array}$ & $\begin{array}{c}\text { Interest Expenses } \\
\text { / GTA }\end{array}$ & $\begin{array}{c}\text { Revenues / } \\
\text { Total Costs }\end{array}$ & NPL / Loans \\
\hline 1984 & 0.1033 & 0.0061 & 0.0961 & 0.0292 & 0.0669 & 1.1399 & 0.0496 \\
1985 & 0.1094 & 0.0065 & 0.0870 & 0.0299 & 0.0572 & 1.1652 & 0.0468 \\
1986 & 0.0978 & 0.0058 & 0.0785 & 0.0303 & 0.0481 & 1.1739 & 0.0458 \\
1987 & 0.0148 & 0.0009 & 0.0794 & 0.0319 & 0.0475 & 1.1822 & 0.0517 \\
1988 & 0.1293 & 0.0078 & 0.0838 & 0.0319 & 0.0519 & 1.1909 & 0.0457 \\
1989 & 0.0760 & 0.0046 & 0.0934 & 0.0320 & 0.0610 & 1.1755 & 0.0486 \\
1990 & 0.0738 & 0.0046 & 0.0932 & 0.0336 & 0.0596 & 1.1702 & 0.0592 \\
1991 & 0.0780 & 0.0051 & 0.0837 & 0.0357 & 0.0480 & 1.1941 & 0.0570 \\
1992 & 0.1277 & 0.0090 & 0.0710 & 0.0368 & 0.0342 & 1.2694 & 0.0473 \\
1993 & 0.1523 & 0.0115 & 0.0653 & 0.0372 & 0.0281 & 1.3038 & 0.0327 \\
1994 & 0.1454 & 0.0110 & 0.0628 & 0.0355 & 0.0274 & 1.3079 & 0.0245 \\
1995 & 0.1461 & 0.0112 & 0.0681 & 0.0342 & 0.0339 & 1.2922 & 0.0242 \\
1996 & 0.1434 & 0.0113 & 0.0669 & 0.0346 & 0.0323 & 1.3067 & 0.0236 \\
1997 & 0.1479 & 0.0116 & 0.0659 & 0.0334 & 0.0325 & 1.3230 & 0.0223 \\
1998 & 0.1391 & 0.0112 & 0.0678 & 0.0352 & 0.0325 & 1.2974 & 0.0218 \\
1999 & 0.1499 & 0.0123 & 0.0654 & 0.0352 & 0.0302 & 1.3463 & 0.0203 \\
2000 & 0.1392 & 0.0113 & 0.0699 & 0.0344 & 0.0355 & 1.3183 & 0.0233 \\
2001 & 0.1299 & 0.0112 & 0.0617 & 0.0336 & 0.0281 & 1.3627 & 0.0270 \\
\hline
\end{tabular}


Table 4: Bank Performance, Number of Banks, and Share of Industry Assets by Bank Size Class, 1984-2001. Return on Equity is net income divided by the average of this year's and the previous year's total equity capital. Return on GTA is net income divided by total assets plus loan and lease loss reserves and allocated transfer risk reserve (a reserve for certain foreign loans). Total Costs / GTA is total expenses (interest expenses + noninterest expenses) divided by total assets plus loan and lease loss reserves and allocated transfer risk reserve. Revenues / Total Costs is operating income divided by total costs. NPL / Loans is nonperforming loans (either past due at least 30 days or on nonaccrual basis) divided by total loans. Proportion of Bank GTA is the sum of GTA for the size class divided by total GTA. Ratios are weighted averages, using the denominators as relative weights. All data are obtained from the December Reports of Condition and Income (Call Reports). Size classes are defined using real 1994 dollars.

\begin{tabular}{|cccccccc|}
\hline Panel A: Commercial Banks with Gross Total Assets Under \$100 million. & & & \\
Year & $\begin{array}{c}\text { Return on } \\
\text { Equity }\end{array}$ & $\begin{array}{c}\text { Return on } \\
\text { GTA }\end{array}$ & $\begin{array}{c}\text { Total Costs / } \\
\text { GTA }\end{array}$ & $\begin{array}{c}\text { Revenues / } \\
\text { Total Costs }\end{array}$ & NPL / Loans & $\begin{array}{c}\text { Number of } \\
\text { Banks }\end{array}$ & $\begin{array}{c}\text { Proportion of } \\
\text { Industry GTA }\end{array}$ \\
\hline 1984 & 0.0818 & 0.0071 & 0.0953 & 1.1579 & 0.0546 & 10,929 & 0.127 \\
1985 & 0.0665 & 0.0058 & 0.0902 & 1.1698 & 0.0609 & 10,727 & 0.119 \\
1986 & 0.0450 & 0.0039 & 0.0830 & 1.1546 & 0.0584 & 10,404 & 0.112 \\
1987 & 0.0537 & 0.0047 & 0.0783 & 1.1666 & 0.0500 & 10,026 & 0.108 \\
1988 & 0.0665 & 0.0059 & 0.0792 & 1.1704 & 0.0445 & 9,555 & 0.103 \\
1989 & 0.0803 & 0.0072 & 0.0848 & 1.1745 & 0.0427 & 9,141 & 0.097 \\
1990 & 0.0738 & 0.0066 & 0.0842 & 1.1669 & 0.0432 & 8,823 & 0.097 \\
1991 & 0.0809 & 0.0073 & 0.0800 & 1.1752 & 0.0413 & 8,466 & 0.096 \\
1992 & 0.1078 & 0.0100 & 0.0674 & 1.2459 & 0.0331 & 8,046 & 0.094 \\
1993 & 0.1148 & 0.0110 & 0.0606 & 1.2758 & 0.0280 & 7,643 & 0.088 \\
1994 & 0.1088 & 0.0108 & 0.0606 & 1.2835 & 0.0251 & 7,202 & 0.079 \\
1995 & 0.1074 & 0.0110 & 0.0653 & 1.2677 & 0.0264 & 6,680 & 0.071 \\
1996 & 0.1044 & 0.0111 & 0.0641 & 1.2797 & 0.0278 & 6,288 & 0.064 \\
1997 & 0.1045 & 0.0112 & 0.0662 & 1.2719 & 0.0264 & 5,983 & 0.057 \\
1998 & 0.0961 & 0.0105 & 0.0671 & 1.2505 & 0.0266 & 5,580 & 0.051 \\
1999 & 0.0907 & 0.0098 & 0.0671 & 1.2422 & 0.0223 & 5,385 & 0.047 \\
2000 & 0.0886 & 0.0097 & 0.0677 & 1.2417 & 0.0246 & 5,084 & 0.042 \\
2001 & 0.0795 & 0.0088 & 0.0642 & 1.2184 & 0.0277 & 4,784 & 0.040 \\
\hline
\end{tabular}

\begin{tabular}{|cccccccc|}
\hline \multicolumn{7}{|c|}{ Panel B: Commercial Banks with Gross Total Assets Between \$100 Million and \$1 Billion } & \\
Year & $\begin{array}{c}\text { Return on } \\
\text { Equity }\end{array}$ & $\begin{array}{c}\text { Return on } \\
\text { GTA }\end{array}$ & $\begin{array}{c}\text { Total Costs / } \\
\text { GTA }\end{array}$ & $\begin{array}{c}\text { Revenues / } \\
\text { Total Costs }\end{array}$ & NPL / Loans & $\begin{array}{c}\text { Number of } \\
\text { Banks }\end{array}$ & $\begin{array}{c}\text { Proportion of } \\
\text { Industry GTA }\end{array}$ \\
\hline 1984 & 0.1189 & 0.0084 & 0.0936 & 1.1601 & 0.0457 & 3,093 & 0.213 \\
1985 & 0.1099 & 0.0078 & 0.0869 & 1.1747 & 0.0482 & 3,147 & 0.206 \\
1986 & 0.0928 & 0.0065 & 0.0789 & 1.1786 & 0.0470 & 3,230 & 0.203 \\
1987 & 0.0872 & 0.0064 & 0.0760 & 1.1919 & 0.0423 & 3,100 & 0.195 \\
1988 & 0.0967 & 0.0071 & 0.0786 & 1.1937 & 0.0379 & 2,997 & 0.190 \\
1989 & 0.1158 & 0.0085 & 0.0848 & 1.2002 & 0.0391 & 3,002 & 0.190 \\
1990 & 0.0972 & 0.0074 & 0.0840 & 1.1963 & 0.0439 & 2,970 & 0.192 \\
1991 & 0.0963 & 0.0074 & 0.0791 & 1.2044 & 0.0434 & 2,938 & 0.195 \\
1992 & 0.1217 & 0.0097 & 0.0659 & 1.2775 & 0.0344 & 2,910 & 0.193 \\
1993 & 0.1319 & 0.0112 & 0.0599 & 1.3084 & 0.0281 & 2,837 & 0.181 \\
1994 & 0.1316 & 0.0115 & 0.0599 & 1.3244 & 0.0231 & 2,770 & 0.168 \\
1995 & 0.1312 & 0.0118 & 0.0644 & 1.3064 & 0.0241 & 2,767 & 0.160 \\
1996 & 0.1299 & 0.0121 & 0.0648 & 1.3175 & 0.0239 & 2,773 & 0.153 \\
1997 & 0.1319 & 0.0123 & 0.0647 & 1.3219 & 0.0218 & 2,735 & 0.144 \\
1998 & 0.1300 & 0.0122 & 0.0644 & 1.3166 & 0.0212 & 2,762 & 0.135 \\
1999 & 0.1381 & 0.0127 & 0.0635 & 1.3306 & 0.0183 & 2,766 & 0.132 \\
2000 & 0.1305 & 0.0119 & 0.0669 & 1.3010 & 0.0200 & 2,808 & 0.126 \\
2001 & 0.1200 & 0.0111 & 0.0626 & 1.2979 & 0.0223 & 2,876 & 0.127 \\
\hline
\end{tabular}


Table 4 continued: Bank Performance, Number of Banks, and Share of Industry Assets by Bank Size Class, 1984-2001.

\begin{tabular}{|cccccccc|}
\hline \multicolumn{7}{|c|}{ Panel C: Commercial Banks with Gross Total Assets Between \$1 Billion and \$10 Billion } \\
Year & $\begin{array}{c}\text { Return on } \\
\text { Equity }\end{array}$ & $\begin{array}{c}\text { Return on } \\
\text { GTA }\end{array}$ & $\begin{array}{c}\text { Total Costs / } \\
\text { GTA }\end{array}$ & $\begin{array}{c}\text { Revenues / } \\
\text { Total Costs }\end{array}$ & NPL / Loans & $\begin{array}{c}\text { Number of } \\
\text { Banks }\end{array}$ & $\begin{array}{c}\text { Proportion of } \\
\text { Industry GTA }\end{array}$ \\
\hline 1984 & 0.1339 & 0.0075 & 0.0925 & 1.1470 & 0.0420 & 310 & 0.266 \\
1985 & 0.1334 & 0.0076 & 0.0837 & 1.1674 & 0.0394 & 341 & 0.274 \\
1986 & 0.1117 & 0.0066 & 0.0759 & 1.1827 & 0.0380 & 351 & 0.273 \\
1987 & 0.0730 & 0.0044 & 0.0765 & 1.2022 & 0.0412 & 357 & 0.284 \\
1988 & 0.1146 & 0.0069 & 0.0803 & 1.2060 & 0.0360 & 355 & 0.293 \\
1989 & 0.0979 & 0.0061 & 0.0879 & 1.1906 & 0.0405 & 346 & 0.279 \\
1990 & 0.0575 & 0.0037 & 0.0876 & 1.2019 & 0.0553 & 333 & 0.274 \\
1991 & 0.0756 & 0.0049 & 0.0823 & 1.2243 & 0.0545 & 325 & 0.287 \\
1992 & 0.1350 & 0.0098 & 0.0690 & 1.3206 & 0.0428 & 331 & 0.287 \\
1993 & 0.1615 & 0.0124 & 0.0624 & 1.3743 & 0.0325 & 327 & 0.286 \\
1994 & 0.1549 & 0.0124 & 0.0630 & 1.3649 & 0.0232 & 319 & 0.264 \\
1995 & 0.1465 & 0.0121 & 0.0679 & 1.3493 & 0.0245 & 331 & 0.244 \\
1996 & 0.1437 & 0.0126 & 0.0670 & 1.3782 & 0.0267 & 312 & 0.221 \\
1997 & 0.1418 & 0.0132 & 0.0685 & 1.4143 & 0.0255 & 282 & 0.184 \\
1998 & 0.1520 & 0.0142 & 0.0700 & 1.3815 & 0.0247 & 285 & 0.167 \\
1999 & 0.1505 & 0.0139 & 0.0660 & 1.3920 & 0.0197 & 283 & 0.159 \\
2000 & 0.1296 & 0.0121 & 0.0697 & 1.3411 & 0.0211 & 268 & 0.137 \\
2001 & 0.1415 & 0.0129 & 0.0643 & 1.3899 & 0.0233 & 274 & 0.141 \\
\hline
\end{tabular}

\begin{tabular}{|c|c|c|c|c|c|c|c|}
\hline \multicolumn{8}{|c|}{ Panel D: Commercial Banks with Gross Total Assets Greater than \$10 Billion } \\
\hline Year & $\begin{array}{l}\text { Return on } \\
\text { Equity }\end{array}$ & $\begin{array}{l}\text { Return on } \\
\text { GTA }\end{array}$ & $\begin{array}{c}\text { Total Costs / } \\
\text { GTA }\end{array}$ & $\begin{array}{l}\text { Revenues / } \\
\text { Total Costs }\end{array}$ & NPL / Loans & $\begin{array}{c}\text { Number of } \\
\text { Banks }\end{array}$ & $\begin{array}{l}\text { Proportion of } \\
\text { Industry GTA }\end{array}$ \\
\hline 1984 & 0.0783 & 0.0036 & 0.1001 & 1.1197 & 0.0548 & 38 & 0.394 \\
\hline 1985 & 0.1126 & 0.0053 & 0.0885 & 1.1577 & 0.0475 & 43 & 0.401 \\
\hline 1986 & 0.1153 & 0.0056 & 0.0788 & 1.1715 & 0.0476 & 50 & 0.412 \\
\hline 1987 & -0.1059 & -0.0051 & 0.0833 & 1.1691 & 0.0638 & 50 & 0.413 \\
\hline 1988 & 0.1948 & 0.0093 & 0.0898 & 1.1847 & 0.0567 & 53 & 0.414 \\
\hline 1989 & 0.0291 & 0.0014 & 0.1027 & 1.1585 & 0.0591 & 61 & 0.434 \\
\hline 1990 & 0.0713 & 0.0036 & 0.1027 & 1.1445 & 0.0709 & 63 & 0.438 \\
\hline 1991 & 0.0671 & 0.0037 & 0.0878 & 1.1744 & 0.0678 & 57 & 0.421 \\
\hline 1992 & 0.1323 & 0.0079 & 0.0753 & 1.2392 & 0.0590 & 54 & 0.426 \\
\hline 1993 & 0.1670 & 0.0110 & 0.0703 & 1.2667 & 0.0357 & 55 & 0.445 \\
\hline 1994 & 0.1545 & 0.0101 & 0.0641 & 1.2761 & 0.0259 & 64 & 0.489 \\
\hline 1995 & 0.1601 & 0.0106 & 0.0698 & 1.2656 & 0.0238 & 73 & 0.526 \\
\hline 1996 & 0.1553 & 0.0106 & 0.0677 & 1.2790 & 0.0217 & 69 & 0.561 \\
\hline 1997 & 0.1619 & 0.0110 & 0.0653 & 1.2994 & 0.0210 & 60 & 0.615 \\
\hline 1998 & 0.1423 & 0.0102 & 0.0679 & 1.2748 & 0.0207 & 66 & 0.648 \\
\hline 1999 & 0.1585 & 0.0120 & 0.0655 & 1.3459 & 0.0208 & 69 & 0.662 \\
\hline 2000 & 0.1479 & 0.0111 & 0.0706 & 1.3214 & 0.0243 & 76 & 0.695 \\
\hline 2001 & 0.1333 & 0.0110 & 0.0609 & 1.3778 & 0.0287 & 69 & 0.692 \\
\hline
\end{tabular}


Table 5: Productivity in the private nonfarm business sector and commercial banking industry, 1967-2000. Column (1) is an index of the output per hour of all persons for the private nonfarm business sector (1996=1), and column (2) shows the natural log differences by year for this sector. Column (3) is the output per hour of all persons for the commercial banking industry (SIC-602, 1987=1), and column (4) shows the natural log differences by year for this industry. Data are from the Bureau of Labor Statistics, www.bls.gov.

\begin{tabular}{|c|c|c|c|c|}
\hline Year & $\begin{array}{c}\text { (1) } \\
\text { Index of Output Per } \\
\text { Hour in the Private } \\
\text { Nonfarm Business } \\
\text { Sector } \\
\end{array}$ & $\begin{array}{c}(2) \\
\text { Productivity Growth } \\
\text { in the Private } \\
\text { Nonfarm Business } \\
\text { Sector }\end{array}$ & $\begin{array}{c}\text { (3) } \\
\text { Index of Output Per } \\
\text { Hour in the } \\
\text { Commercial Banking } \\
\text { Industry }\end{array}$ & $\begin{array}{l}\text { (4) } \\
\text { Productivity Growth } \\
\text { in the Commercial } \\
\text { Banking Industry }\end{array}$ \\
\hline 1967 & 61.8 & & 70.9 & \\
\hline 1968 & 63.7 & 0.0303 & 72.3 & 0.0196 \\
\hline 1969 & 63.8 & 0.0016 & 71.1 & -0.0167 \\
\hline 1970 & 64.9 & 0.0171 & 72.5 & 0.0195 \\
\hline 1971 & 67.6 & 0.0408 & 75.1 & 0.0352 \\
\hline 1972 & 69.9 & 0.0335 & 76.5 & 0.0185 \\
\hline 1973 & 72.1 & 0.0310 & 81.2 & 0.0596 \\
\hline 1974 & 71.0 & -0.0154 & 76.1 & -0.0649 \\
\hline 1975 & 73.0 & 0.0278 & 76.3 & 0.0026 \\
\hline 1976 & 75.8 & 0.0376 & 80.5 & 0.0536 \\
\hline 1977 & 76.9 & 0.0144 & 84.7 & 0.0509 \\
\hline 1978 & 77.8 & 0.0116 & 85.8 & 0.0129 \\
\hline 1979 & 77.5 & -0.0039 & 84.1 & -0.0200 \\
\hline 1980 & 77.3 & -0.0026 & 78.5 & -0.0689 \\
\hline 1981 & 78.3 & 0.0129 & 77.8 & -0.0090 \\
\hline 1982 & 78.0 & -0.0038 & 80.1 & 0.0291 \\
\hline 1983 & 81.4 & 0.0427 & 87.1 & 0.0838 \\
\hline 1984 & 83.2 & 0.0219 & 89.6 & 0.0283 \\
\hline 1985 & 84.4 & 0.0143 & 94.3 & 0.0511 \\
\hline 1986 & 87.1 & 0.0315 & 96.2 & 0.0199 \\
\hline 1987 & 87.5 & 0.0046 & 100.0 & 0.0387 \\
\hline 1988 & 88.6 & 0.0125 & 102.8 & 0.0276 \\
\hline 1989 & 89.2 & 0.0067 & 104.8 & 0.0193 \\
\hline 1990 & 90.3 & 0.0123 & 107.7 & 0.0273 \\
\hline 1991 & 91.4 & 0.0121 & 110.1 & 0.0220 \\
\hline 1992 & 94.8 & 0.0365 & 111.0 & 0.0081 \\
\hline 1993 & 95.3 & 0.0053 & 118.5 & 0.0654 \\
\hline 1994 & 96.5 & 0.0125 & 121.7 & 0.0266 \\
\hline 1995 & 97.5 & 0.0103 & 126.4 & 0.0379 \\
\hline 1996 & 100.0 & 0.0253 & 129.7 & 0.0258 \\
\hline 1997 & 102.0 & 0.0198 & 133.0 & 0.0251 \\
\hline 1998 & 104.7 & 0.0261 & 132.6 & -0.0030 \\
\hline 1999 & 107.1 & 0.0227 & 135.9 & 0.0246 \\
\hline 2000 & 110.7 & 0.0331 & 143.2 & 0.0523 \\
\hline \multicolumn{5}{|c|}{$\underline{\text { Average Productivity Growth Rates over Selected Intervals }}$} \\
\hline $1967-1973$ & & 0.0257 & & 0.0226 \\
\hline 1973-1995 & & 0.0137 & & 0.0201 \\
\hline $1995-2000$ & & 0.0254 & & 0.0250 \\
\hline $1967-1973$ & & 0.0257 & & 0.0226 \\
\hline 1973-1982 & & 0.0087 & & -0.0015 \\
\hline $1982-2000$ & & 0.0195 & & 0.0323 \\
\hline
\end{tabular}

